\title{
ASIA'S INDUSTRIAL TRANSFORMATION: THE ROLE OF MANUFACTURING AND GLOBAL VALUE CHAINS (PART 1)
}

Jesus Felipe

NO. 549

July 2018
ADB ECONOMICS WORKING PAPER SERIES 


\section{Asia's Industrial Transformation: The Role of Manufacturing and Global Value Chains (Part 1)}

Jesus Felipe

No. 549 | July 2018
Jesus Felipe (jfelipe@adb.org) is an Advisor in the Economic Research and Regional Cooperation

Department of the Asian Development Bank.

This paper has been prepared as background material for the forthcoming volume on 50 Years of Asian Growth and Transformation: Roles of Technology, Markets, and Policies. I am grateful to Yasuyuki Sawada and the participants at an ADB workshop for their comments and suggestions. The usual disclaimer applies. 
(C) 2018 Asian Development Bank

6 ADB Avenue, Mandaluyong City, 1550 Metro Manila, Philippines

Tel +632632 4444; Fax +6326362444

www.adb.org

Some rights reserved. Published in 2018.

ISSN 2313-6537 (print), 2313-6545 (electronic)

Publication Stock No. WPS189457-2

DOI: http://dx.doi.org/10.22617/WPS189457-2

The views expressed in this publication are those of the authors and do not necessarily reflect the views and policies of the Asian Development Bank (ADB) or its Board of Governors or the governments they represent.

ADB does not guarantee the accuracy of the data included in this publication and accepts no responsibility for any consequence of their use. The mention of specific companies or products of manufacturers does not imply that they are endorsed or recommended by ADB in preference to others of a similar nature that are not mentioned.

By making any designation of or reference to a particular territory or geographic area, or by using the term "country" in this document, $A D B$ does not intend to make any judgments as to the legal or other status of any territory or area.

This work is available under the Creative Commons Attribution 3.0 IGO license (CC BY 3.0 IGO)

https://creativecommons.org/licenses/by/3.0/igo/. By using the content of this publication, you agree to be bound by the terms of this license. For attribution, translations, adaptations, and permissions, please read the provisions and terms of use at https://www.adb.org/terms-use\#openaccess.

This CC license does not apply to non-ADB copyright materials in this publication. If the material is attributed to another source, please contact the copyright owner or publisher of that source for permission to reproduce it. $\mathrm{ADB}$ cannot be held liable for any claims that arise as a result of your use of the material.

Please contact pubsmarketing@adb.org if you have questions or comments with respect to content, or if you wish to obtain copyright permission for your intended use that does not fall within these terms, or for permission to use the ADB logo.

Notes:

In this publication, "\$” refers to United States dollars.

ADB recognizes "China" as the People's Republic of China, and "Korea" and "South Korea" as the Republic of Korea. Corrigenda to ADB publications may be found at http://www.adb.org/publications/corrigenda. 


\section{CONTENTS}

TABLES, FIGURES, AND BOXES iv

ABSTRACT V v v v v

$\begin{array}{ll}\text { I. INTRODUCTION } & 1\end{array}$

II. STRUCTURAL TRANSFORMATION IN DEVELOPING ASIA 3

III. MANUFACTURING AND ECONOMIC DEVELOPMENT: 8

THE ENGINE OF GROWTH HYPOTHESIS
A. $\quad$ Understanding the Role of Manufacturing in Development:

Two Important Questions

B. Export-Led Growth and Industrialization: Relaxing the Balance-of-Payments 18

Constraint

C. The Industrialization Experiences of Japan and the Republic of Korea 21

D. The Recent Deindustrialization Debate 32

$\begin{array}{lr}\text { REFERENCES } & 39\end{array}$ 


\section{TABLES, FIGURES, AND BOXES}

\section{TABLES}

1 Regression of Nonmanufacturing Growth on Manufacturing Growth, 1961-2016 13

2 Regression of Nonmanufacturing Growth on Manufacturing Growth, 1961-1996 15

3 Regression of Nonmanufacturing Growth on Manufacturing Growth, 2000-2016 16

$4 \quad$ Share in Country's Total Exports, by Product Complexity, Average 2001-2007 24

5 The 10 Most Complex Products and Their Exporters 25

\section{FIGURES}

$1 \quad$ Agricultural Output and Employment Shares versus Per Capita GDP, 1970-2016 3

2 Industry Output and Employment Shares versus Per Capita GDP, 1970-2016 4

3 Services Output and Employment Shares versus Per Capita GDP, 1970-2016 5

$4 \quad$ Total Labor Productivity $\quad 7$

5 Output Growth versus Change in Manufacturing Output Share 12

$6 \quad$ Industrialization in Employment and Output 33

$7 \quad$ Manufacturing Shares and Year Peak was Attained 33

$8 \quad$ Year Peak was Attained and Income per Capita 34

9 Share of Manufacturing in Global Output with Regional Contributions 35

10 Share of Manufacturing in Global Employment with Regional Contributions 36

\section{BOXES}

1 Manufacturing and Increasing Returns to Scale 2

$2 \quad$ Why Manufacturing is the Engine of Growth 9

3 The Literature on the Engine of Growth Hypothesis 10 


\begin{abstract}
This paper argues that the single most important factor that explains East Asia's development success was its fast structural transformation toward industrialization, manufacturing in particular. Workers moved out of agriculture into manufacturing, and the sector diversified and upgraded its structure. Manufacturing activities are subject to increasing returns to scale, and many manufacturing goods have high income elasticities of demand. For these reasons, manufacturing is referred to as the "engine of growth." It is in the context of industrialization that openness played an important role in East Asia's success, i.e., the connection between "export-led growth" (the relaxation of the balance-of-payments constraint on foreign exchange) and industrialization. Part 1 of the paper documents the extent of structural transformation in developing Asia. Second, it analyzes the relationship between the exportled growth model (i.e., the relaxation of the balance-of-payments constraint on foreign exchange) and industrialization. Finally, it reviews the industrialization experiences of Japan and the Republic of Korea, and discusses the recent deindustrialization debate.
\end{abstract}

Keywords: balance-of-payment constraint, deindustrialization, engine of growth, export-led growth, industrialization, manufacturing, structural transformation

JEL codes: $\mathrm{O} 10, \mathrm{O} 14, \mathrm{O} 25$ 


\section{INTRODUCTION}

Aggregate growth is related to the rate of expansion of the sector with the most favorable growth characteristics. There is plenty of historical work and empirical evidence that suggests that there is something special about industry, and in particular about manufacturing, which makes it different from agriculture and from most services, and which allows it to generate high growth rates. This key characteristic is that activities in this sector have a great capacity for productivity growth, externalities (technical as well as pecuniary), and increasing returns to scale. Adam Smith ([1776] 2003) and Allyn Young (1928) already noted this special characteristic (see Box 1). For this reason, the literature has referred to manufacturing as the engine of growth. ' Indeed, this idea is so well settled in the literature that the terms "industrialized" and "high income" were used interchangeably through much of the 20th century. ${ }^{2}$

This paper discusses the importance of manufacturing in Asia's development. A central explanation of the region's fast growth starting in the second half of the 20th century is that these economies understood early on that the transition to manufacturing was key to generate high growth rates and to develop in general. The shift from agriculture into manufactures has always been central to a country's development.

Indeed, the transition into manufacturing became a key piece of Asia's development in a context of export-led growth, where Asian companies saw the whole world as their market. They realized that they had to export, in particular manufactures, to pay for their import requirements. In other words, manufacturing and exports go hand in hand in explaining Asia's development.

The belief in the relevance of manufacturing for development is patent by the fact that India's 2011 National Manufacturing Policy aims at raising the share of manufacturing in gross domestic product (GDP) to 25\% and creating 100 million manufacturing jobs, priorities reinforced by the current government's "Make in India" campaign. The Philippines, seeking to reverse almost half a century of slow deindustrialization, is developing a comprehensive manufacturing road map. Indonesia, seeking to avoid the resource curse, passed a new Industry Law in 2014. Even the People's Republic of China (PRC), the "factory of the world," is pushing high-technology industries and the use of technology in manufacturing through its "Made in China 2025" program. Developed countries like the United States (US), Australia, and the members of the European Union are also interested in industrializing, or rather, reindustrializing after decades of deindustrializing. These plans, particularly in late industrializing societies, often involve big changes to policies and institutions, with land rights, labor law, educational practices, trade and investment rules, and financial and fiscal arrangements all on the table (Helper, Krueger, and Wial 2012; Felipe 2015).

The rest of the paper is structured as follows. Section II documents the extent of structural transformation in developing Asia. In section III, we review the characteristics that confer manufacturing the label of engine of growth, the connection between export-led growth and industrialization, the industrialization experiences of Japan and the Republic of Korea, and the recent deindustrialization debate.

1 For some classic and more recent contributions, see Kaldor (1966); Chenery, Robinson, and Syrquin (1986); Amable (2000); Fagerberg (2000); Peneder (2003); Rodrik (2009); Szirmai (2012); Szirmai and Verspagen (2011); and UNIDO (2013).

2 Today, it is known that some service activities do have properties similar to these, i.e., they are subject to increasing returns to scale and generate sustained productivity growth, the same as manufacturing. 


\section{Box 1: Manufacturing and Increasing Returns to Scale}

The literature has documented that countries that grow fast tend to be those where the share of manufacturing in gross domestic product increases fast. Significant examples are the East Asian economies during the 1970s and 1980s. This is not an accident. Indeed, many economists have argued that it is impossible to understand growth and development without taking a sectoral approach, distinguishing between increasing returns activities (e.g., manufacturing) and diminishing returns activities (e.g., primary agriculture). The idea of increasing returns to scale goes back to Adam Smith ([1776] 2003). It was forgotten for a long time and then picked up again by Allyn Young (1928).

One of Adam Smith's most important contributions to economics was the notion of increasing returns, a central concept of modern growth theories. For Smith, increasing returns are based on the division of labor, or gains derived from specialization. This idea provided Adam Smith an optimistic view of economic progress, as a self-generating process, in contrast to that of other classical economists. The idea of increasing returns is extremely powerful and has huge significance in economics. This is the basis for distinguishing between activities subject to increasing returns to scale on the one hand, and subject to diminishing returns, on the other. The former means rising labor productivity and per capita income, and no limits on the employment of labor set by the subsistence wage. Rich, developed countries tend to specialize in increasing returns activities, while poor developing countries tend to specialize in diminishing returns activities. Adam Smith was the first economist to grasp the essential idea that not all products have the same consequences for development, namely that if a country wants to develop it needs to get into products/activities subject to increasing returns to scale and with a relatively high income elasticity of demand. This is the essence of the export-led industrialization strategy that Japan and other successful Asian countries followed.

Smith recognized three ways in which labor productivity increases through specialization. First, through the increased dexterity or skill of labor, what economists refer as 'learning by doing.' Second, through the time saved and which otherwise would be lost during the process of switching from one activity into another. And third, through the greater scope for capital accumulation, that is, the ability to break up complex processes into simpler processes permitting the use of machinery, which raises productivity still further.

This view of growth and development, i.e., as a cumulative interactive process based on the division of labor and increasing returns in industry, lay dormant until the economist Allyn Young revived it in a 1928 paper entitled 'Increasing Returns and Economic Progress.' 3 In this paper, he provided a view of increasing returns as a macroeconomic phenomenon. Indeed, for Young, increasing returns are not simply confined to factors that raise productivity within individual industries, but are related to the output of all industries, which he argued should be seen as interrelated. This means that a larger market for one good confers a positive externality on others. Young argued that, under certain conditions, change will become progressive and propagate throughout the economy in a cumulative way. What is needed for this is the presence of increasing returns and that the demand for products be price elastic, i.e., the more the exchange value falls proportionately, the more will be purchased. The process of expansion will stop when demand ceases to be elastic and returns do not increase. To take an example, think of the textile and steel industries, where both conditions are met. As the supply of steel increases, its relative price decreases. If demand is elastic, textile producers demand proportionately more steel. Then textile production will increase and its relative price will also fall. If demand is elastic, steel producers will demand proportionately more textiles, and so on.

It is very important to understand that this process could not happen with diminishing returns activities, such as traditional agriculture, where price demand is inelastic. This provides the intuition for why both historically and still today, development is largely associated to the process of industrialization (including some modern services).

Source: Author.

3 One possible reason is that after Chapter 4 of Book I of the Wealth of Nations, Adam Smith abandoned the assumption of increasing returns in favor of constant returns. 


\section{STRUCTURAL TRANSFORMATION IN DEVELOPING ASIA}

During the last 4 decades, most economies in developing Asia have undergone massive structural change, in particular in the composition of their output and employment structures (sectoral shares). Starting in the 1960s and 1970s, the structures of production and exports of the East Asian economies underwent significant changes. Specifically, the share of manufacturing value added in GDP, and that of manufacturing employment in total employment, increased significantly. Starting with Japan and the East Asian economies, then Southeast Asia, and then the PRC, these economies experienced significant economic transformation: workers left the countryside (primary agriculture) and went to the cities, while, concomitantly, the production of manufactures increased significantly.

Figure 1: Agricultural Output and Employment Shares versus Per Capita GDP, 1970-2016 (logarithmic scale)
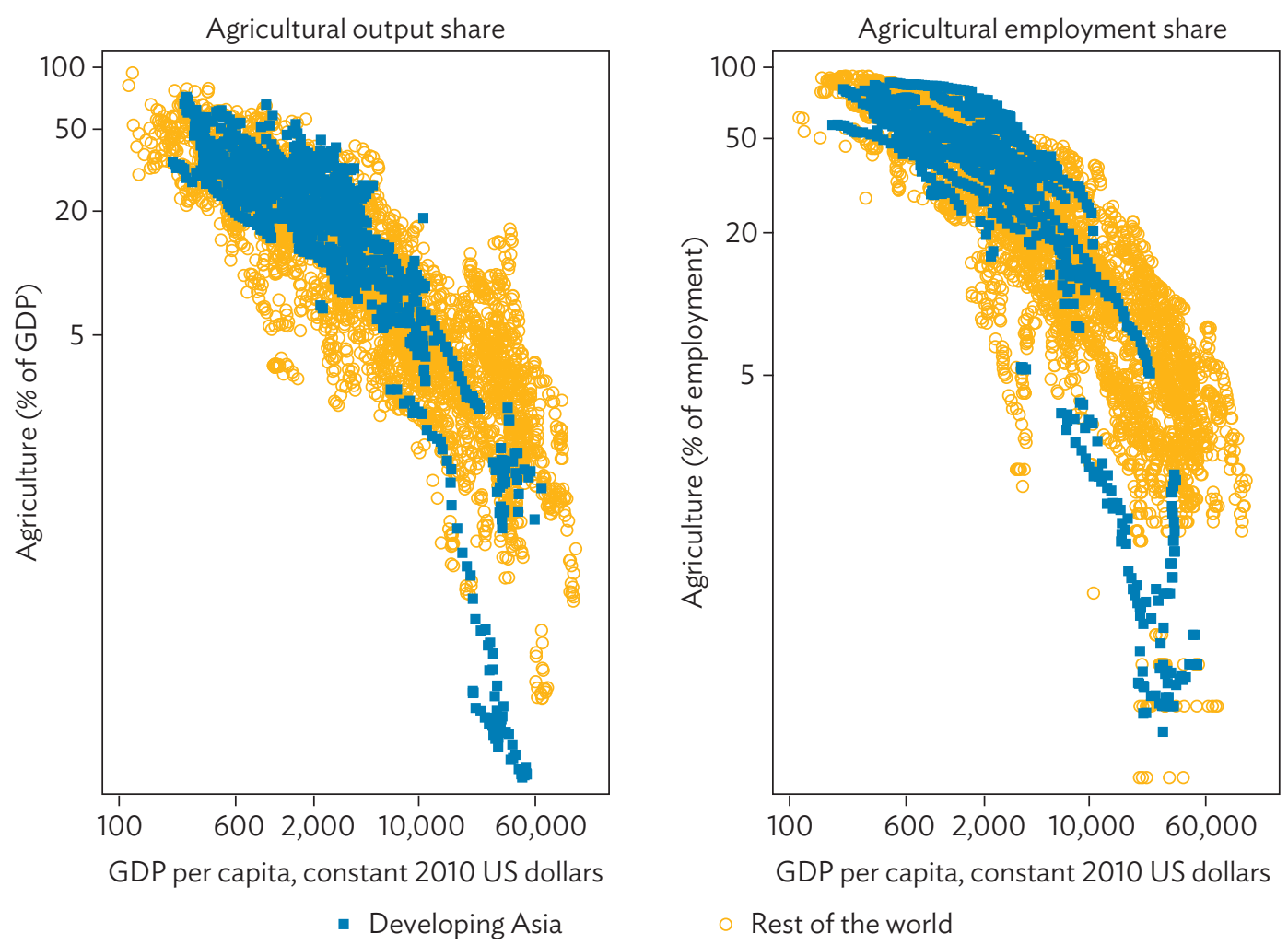

$\mathrm{GDP}=$ gross domestic product, $\mathrm{US}=$ United States.

Note: Both axes are logarithmic scales. The year of data for each country vary with availability of data. The earliest is 1970 and the latest is 2016 .

Sources: World Bank's World Development Indicators online database (accessed 18 January 2018); Timmer, Marcel, Gaaitzen J. de Vries, and Klaas de Vries. 2015. "Patterns of Structural Change in Developing Countries." In Routledge Handbook of Industry and Development, edited by John Weiss and Michael Tribe, 65-83. London and New York: Routledge; Author's estimates. 
Figures 1, 2, and 3 show scatterplots of the output and employment shares of agriculture, industry, and services vis-à-vis income per capita, pooling data since 1970 for the whole world. Figure 1 shows that the shares of agricultural output (in total output) and employment (in total employment) decline as countries become richer. Figure 2 shows that as countries' income per capita increases so do the shares of output and employment in industry, although there seems to be a point beyond which these two shares start declining (i.e., an inverted-U shape relationship). Figure 2 also shows a wide dispersion in these shares for a given income per capita. Finally, Figure 3 shows that the shares of output and employment in services increase as income per capita increases. The relationships described between sectors' shares and income per capita are referred to as the "logistic pattern." It is based on Engle's law (demand explanation) and it is the result of the differential productivity growth rates across sectors (supply explanation).

Figure 2: Industry Output and Employment Shares versus Per Capita GDP, 1970-2016 (logarithmic scale)
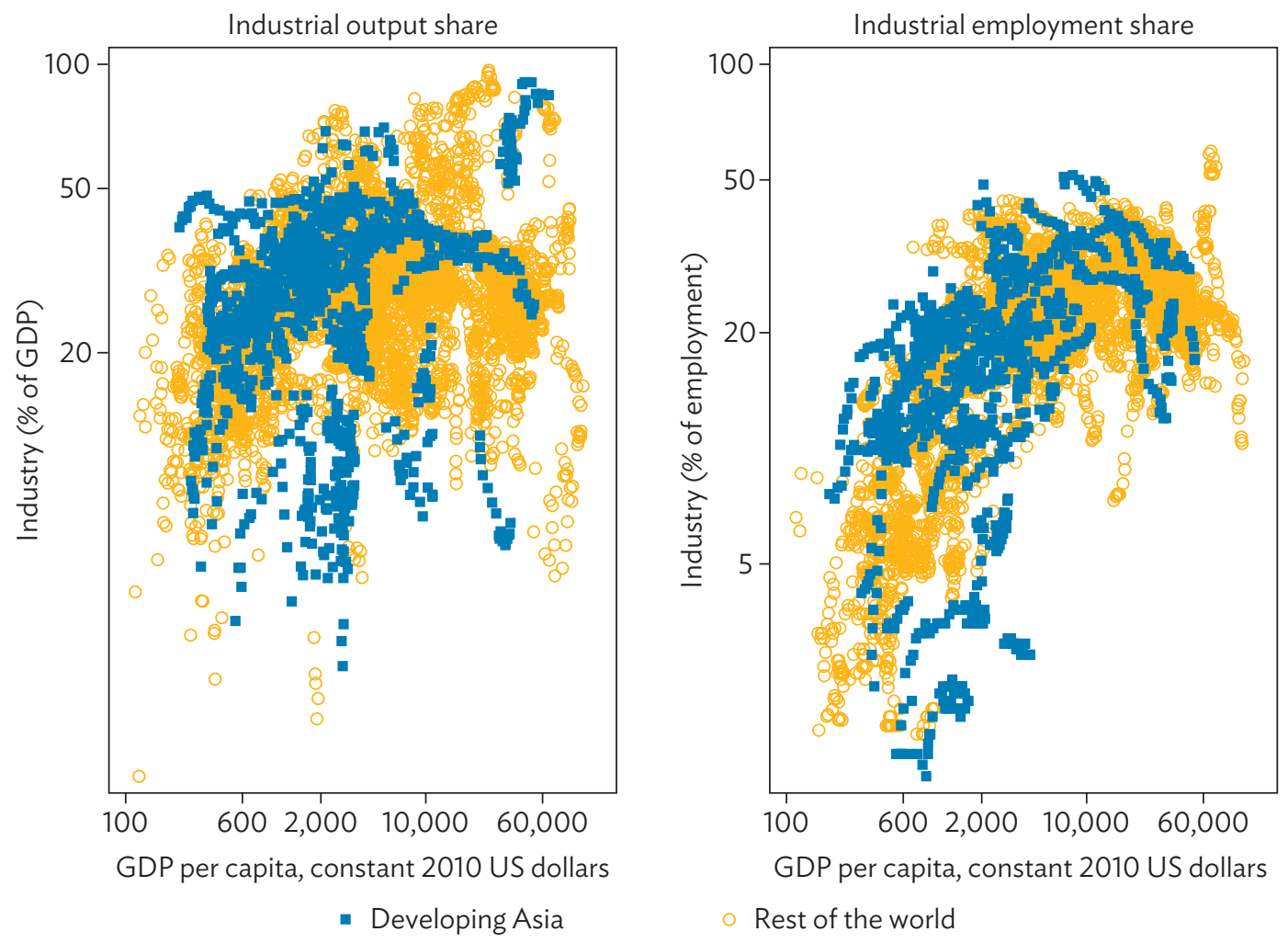

GDP = gross domestic product, US = United States.

Note: Both axes are logarithmic scales. The year of data for each country vary with availability of data. The earliest is 1970 and the latest is 2016.

Sources: World Bank's World Development Indicators online database (accessed 18 January 2018); Timmer, Marcel, Gaaitzen J. de Vries, and Klaas de Vries. 2015. "Patterns of Structural Change in Developing Countries." In Routledge Handbook of Industry and Development, edited by John Weiss and Michael Tribe, 65-83. London and New York: Routledge; Author's estimates. 
The share of agricultural output in total output has declined significantly across developing Asia during the last decades. Especially significant are the declines that occurred in the PRC and India, in the former from about 32\% in the 1970s to about $9 \%$ in 2010-2016, and in the latter from about $40 \%$ to about 18\% (during the same period). Parallel to this decline, there has been an increase in the share of services also in all regions. The share of industry has increased significantly in some parts of developing Asia (e.g., Association of Southeast Asian Nations [ASEAN] -4, other Southeast Asia, other South Asia), remained about the same in the PRC and increased by a small margin in India.

Figure 3: Services Output and Employment Shares versus Per Capita GDP, 1970-2016 (logarithmic scale)
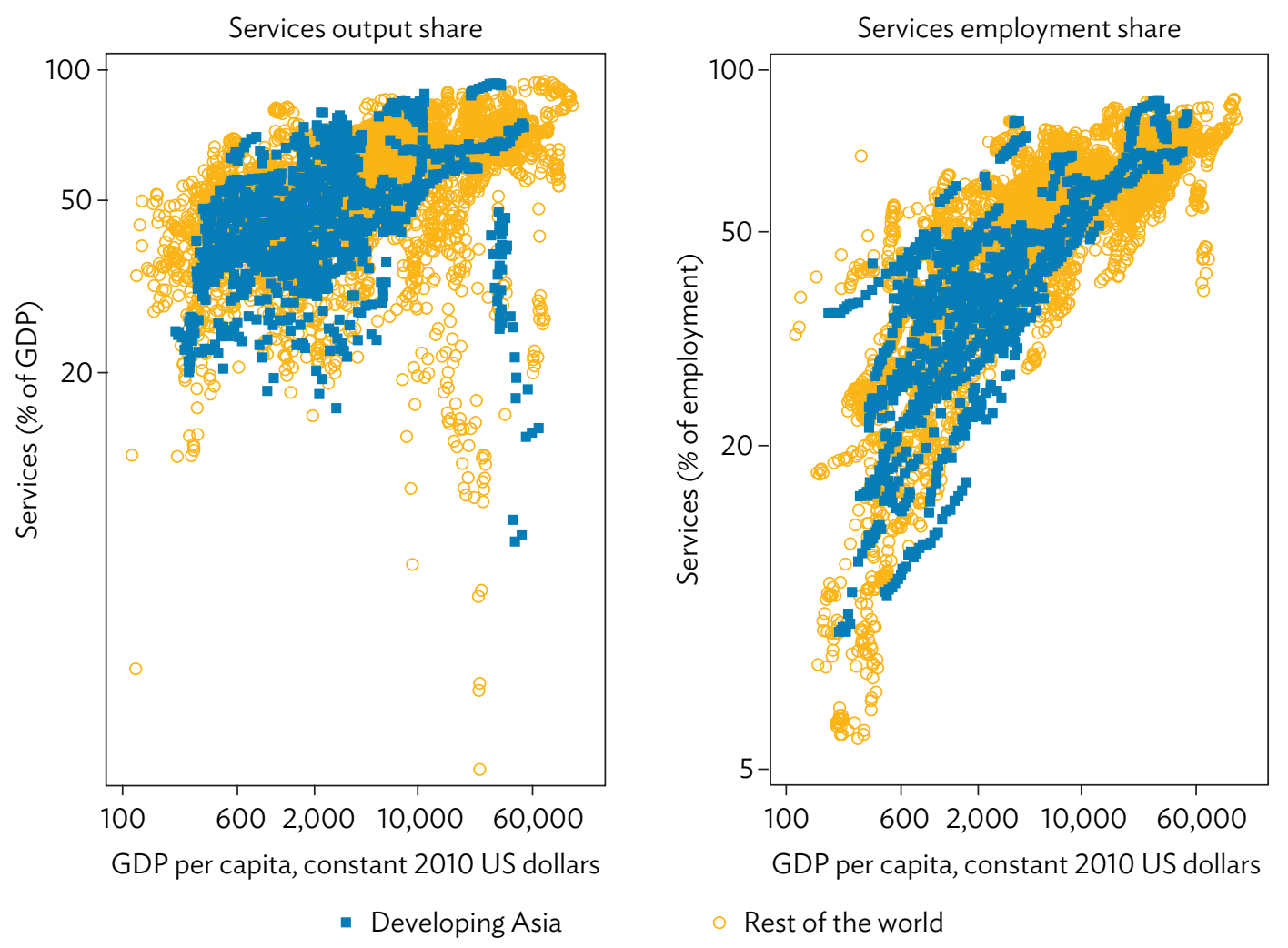

- Rest of the world

GDP = gross domestic product, $U S=$ United States.

Note: Both axes are logarithmic scales. The year of data for each country vary with availability of data. The earliest is 1970 and the latest is 2016.

Sources: World Bank's World Development Indicators online database (accessed 18 January 2018); Timmer, Marcel, Gaaitzen J. de Vries, and Klaas de Vries. 2015. "Patterns of Structural Change in Developing Countries." In Routledge Handbook of Industry and Development, edited by John Weiss and Michael Tribe, 65-83. London and New York: Routledge; Author's estimates.

The share of employment in agriculture has also declined across developing Asia. In general, the decline in agricultural employment has occurred at a much slower pace than that in output. As in the case of the output share, there has been a generalized increase in the share of employment in services in all regions. Employment in industry has increased significantly in the ASEAN-4 countries (except the Philippines) and in the PRC and India; it has increased across most of Central and West Asia, although by only a small margin in many of them; and has suffered a decline in the newly industrialized economies (NIEs) (especially in Hong Kong, China). 
The NIEs have undergone severe deindustrialization as manufacturing has lost significant weight in total output between the 1970s and 2000-2004 (see Rowthorn and Ramaswamy 1997, 1999; and Pieper 2000). This need not be a negative phenomenon, but the natural consequence of the industrial dynamism of these economies, i.e., the transition to service-led economies. It is a feature of economic development that reflects their success. In terms of manufacturing employment, most NIEs have clearly deindustrialized (except Taipei,China), especially Hong Kong, China, where the share decreased by about 40 percentage points in roughly 5 decades. The declines in the other two economies are not as significant. Rowthorn and Ramaswamy $(1997,1999)$ have noted that this group of countries underwent a process similar to that of the Organisation for Economic Co-operation and Development (OECD) countries, although it must be noted that it is a process that has affected mainly Hong Kong, China and Singapore, and to a much lesser extent the Republic of Korea. ${ }^{4}$ This is the result of transferring production facilities to the PRC. In the Republic of Korea, the share of manufacturing has remained at about $17 \%-20 \%$ since the 2000 s.

Output and employment manufacturing shares of the ASEAN-4 countries have increased significantly. The exception is the Philippines, whose manufacturing output share was the highest among the ASEAN-4 in the 1970s, but by 2010-2016 it had decreased by about 5 percentage points, and was the lowest in the group.

Although Indonesia, Malaysia, and Thailand are cases of what can be labeled as "successful industrialization," this must be qualified with the following two observations. First, other than Malaysia; the PRC; the Republic of Korea; and Taipei,China, no other economy in developing Asia had in 2010-2016 a share of employment in manufacturing that was significantly higher than that of the OECD countries. Second, in terms of labor productivity (Figure 4), there is a large differential between most developing Asian economies and the OECD average. Indeed, it appears that many economies across developing Asia have industrialized at low levels of productivity. This is the result of the fact that the product mix of new employment has been toward relatively low-productivity industries, most often services.

Other than the NIEs, today's level of productivity in the rest of the developing Asia is still below the OECD average during the early 1970s. The level of productivity in the secondary sector is significantly higher than that in agriculture. And the level of labor productivity in the service sector is above that in industry and manufacturing. Labor productivity in industry nearly doubled in Indonesia between 1975-1979 and 2015-2016, but in the Philippines it increased by only less than 50\%. In most countries, labor productivity in agriculture is still very low.

Only the NIEs have achieved labor productivity levels that approach those of the OECD countries, and within this group, Singapore and Hong Kong, China are city-states with very small rural sectors. The Republic of Korea and Taipei,China are significantly behind. Moreover, although in all Asian countries shown productivity has improved significantly (with the noted exception of the Philippines), the absolute gap with respect to the OECD productivity level has widened. In the case of Malaysia, the country with the highest productivity levels outside the OECD and the NIEs, the absolute productivity differential with respect to the OECD in industry has increased by over one-half, from $\$ 51,045$ in 1975-1979 to $\$ 78,217$ in 2015-2016, despite the fact that Malaysia's productivity in industry increased by a factor of 1.7. In other countries and sectors the gap has widened by even larger amounts.

4 Wan (2004, pp.258-60) argues that both public and private circles in Hong Kong, China "remain interested in 'reindustrialization"' after 1997. The reasons are twofold. First, deindustrialization brings hardship for the poor, worsens income distribution and, as a consequence, threatens social stability. Second, Hong Kong, China has specialized in services that are PRC oriented. However, Hong Kong, China may lose this privileged position once Shanghai flourishes as a service center. Wan goes on to argue that both private and private circles in Hong Kong, China tried to prevent the city's deindustrialization, but could not stop it due to the lack of any industrial policy in the 1970s. 
ADB (2007) provides evidence that the manufacturing sectors of a number of Asian economies, especially Malaysia; the Republic of Korea; Singapore; and Taipei,China, have undergone important transformations and shifted their manufacturing output to more technology- and scale-intensive subsectors. This shift upward is an important component of what structural change is about, as the production of more sophisticated manufactured products leads to faster growth, for it enlarges the potential for catch-up. In the PRC and India, the shift to more technology- and scale-intensive subsectors is taking place more slowly; while in most other Asian countries the evidence is lacking.

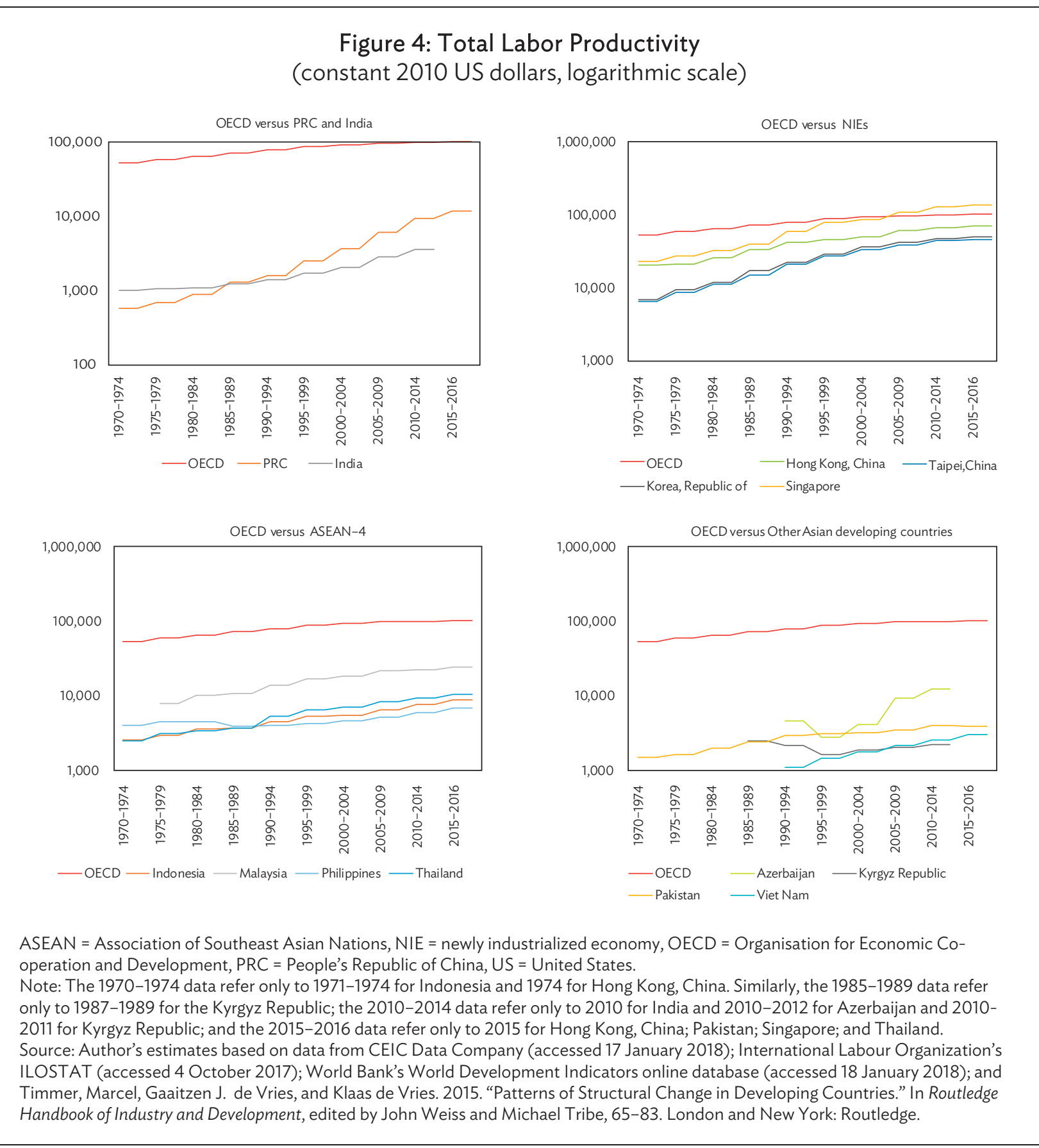


Although in decline with respect to the average of the 1980s, the share of the PRC's manufacturing subsector in total output has been traditionally very high. It still accounts for about $30 \%$ of total output, only matched in developing Asia by Taipei,China. The share of manufacturing employment, on the other hand, has increased from about $15 \%$ in the 1980 s to around $18 \%$ now. The PRC has effectively lost millions of manufacturing jobs since the 1990s due to the restructuring process of its state-owned enterprises since the economic reform period began in 1979. However, it is worth noting that this decline is occurring at a much lower level of income than it did in the industrial countries. Moreover, less than fifth of the PRC's labor force is employed in manufacturing, mining, and construction combined (Banister 2005). The share of India's manufacturing output has remained stable at about $18 \%$ since the 1970 s, while the share of manufacturing employment has been at around $11 \%$ during the periods under consideration.

\section{MANUFACTURING AND ECONOMIC DEVELOPMENT: THE ENGINE OF GROWTH HYPOTHESIS}

Historically, countries have always cared about manufacturing. Indeed, the nascent nation states of Europe during the 15th and 16th centuries, realized that making and selling manufactures (not raw materials), together with international trade, was the route to richness (Reinert 2007).

There is a large literature that explains and documents, both theoretically and empirically, why manufacturing matters and why, as a result, the sector is labeled the engine of growth. A reading of the literature indicates that there are at least four theoretical reasons for nations seeking economic growth to target manufacturing, and specifically. First, shifting labor from traditional, low-productivity sectors of the economy into higher-productivity manufacturing lifts labor productivity-an effect that grows with the rate of manufacturing job creation (Lewis 1955; Kaldor 1966; Chenery, Robinson, and Syrquin 1986). As productivity is higher in manufacturing than in agriculture, the transfer of resources from the former to the latter generates a 'structural bonus.' Likewise, the transfer of resources from manufacturing to services creates, in general, a 'structural burden' or Baumol's (1967) disease: as the share of the service sector increases, aggregate per capita growth will tend to slow down.

Second, manufacturing has a potential for productivity catch-up that is unmatched by most services. Rodrik (2013) shows that manufacturing exhibits unconditional convergence in labor productivity - national manufacturing industries that start farther away from the labor productivity frontier experience significantly faster productivity growth even without conditioning on variables such as domestic policies, human capital, geography, or institutional quality. Arithmetically, this effect will be larger the more manufacturing jobs there are.

Third, to the extent that manufactured goods have high income elasticities of demand (higher than those of agricultural products), and are produced under increasing returns to scale, industrialization sets in motion a virtuous cycle (Rosenstein-Rodan 1943, Murphy et al. 1989). As costs in some manufacturing industries drop, the demand for all manufactured goods increases, in turn causing more investment in manufacturing activity and higher incomes, which spur further demand increases and cost reductions. Moreover, as per capita income rises, the share of agricultural expenditures in total expenditures declines and the share of expenditures on manufacturing goods increases (Engel's law). The relatively high income elasticity of demand of manufactures reflects the nonprice characteristics of a good. Countries specializing in agricultural and primary products will not profit from expanding world markets for manufacturing products. 
There is a fourth reason to care about manufacturing, related to the balance of payments (Thirlwall 1979): as income per capita increases, so does per capita demand for manufactured products. If a developing country does not have a strong manufacturing sector, it will end up running a trade deficit in manufactured goods. To cover this deficit, the country will either have to borrow, or to secure an equally large surplus of nonmanufactured goods (e.g., services, minerals, food, etc.). Either route is very difficult for the typical developing country.

The first two mechanisms are activated by manufacturing employment rather than output. And, while the third ("big push") mechanism relies on output, rather than employment growth, it should diminish in importance as globalization makes countries less reliant on local demand to propel industrialization. It follows that in a world of export-led industrialization, manufacturing employment is likely to be a stronger predictor of prosperity than manufacturing output. Box 2 provides a summary of additional arguments about why manufacturing matters.

\section{Box 2: Why Manufacturing is the Engine of Growth}

Empirically, there is a close relationship between the level of per capita income today and the share of manufacturing in gross domestic product (GDP) in the past, as well as between industrial growth and the growth of overall GDP. It is hard to find similar cross-section relations between the growth of GDP and the growth of the agricultural sector, although this does not mean that the sector is irrelevant and that it should be neglected. 5 The relationship between the growth of GDP and the growth of services is stronger but there is reason to believe that the direction of causation may be the other way around, from the growth of GDP to service growth since the demand for many services is derived from the demand for manufacturing output itself. Recent research seems to indicate that some modern services have the production characteristics, i.e., static and dynamic scale economies, to induce fast growth (Maroto-Sánchez and Cuadrado-Roura 2009).

Other reasons why manufacturing matters are as follows:

(i) Manufacturing offers significant opportunities for capital accumulation. The latter can be more easily realized in spatially concentrated manufacturing than in spatially dispersed agriculture, or than in many service activities. Capital accumulation is the result investment, directly a source of growth.

(ii) The manufacturing sector also offers special opportunities for economies of scale.

(iii) A significant portion of technical progress occurs in manufacturing. Overall, manufacturing is the main source of technology-driven productivity growth in modern economies. It is known that the capital goods subsector has been the 'learning center' of capitalism in technological terms. It has also been the source of organizational innovation.

(iv) Linkage and spillover effects are stronger in manufacturing than possibly in any other sector of the economy. Linkage effects refer to the intersectoral purchases and sales, while spillover effects refer to the knowledge flows between sectors. Both linkage and spillovers are strong both within manufacturing and between manufacturing and services and agriculture. For example, manufacturing has been the main source of demand for high-productivity activities in other industries (the main customers of high-productivity service activities are manufacturing firms).

(v) As the producer of physical and nonperishable products, manufacturing has higher tradability than agriculture and services. Indeed, one important aspect of manufacturing when compared with services and agriculture is the tradability of its output. Despite improvements in transportation-such as containerization, refrigeration, port efficiency and other aspects of the 'timeliness' of trade-and in information and communication technology (ICT) that have increased the possibilities for international trade in agricultural products and services, manufactured goods remain more freely traded than products from either of these two sectors. A development strategy based upon manufacturing therefore allows for a country to become increasingly engaged in international trade, and in exporting in particular.

Source: Author.

5 Indeed, a classic failure of postwar policy has been to favor manufacturing at the expense of agriculture, in many parts of the developing world. This has tended to retard agricultural development and indirectly this has harmed industrial development and, consequently, overall growth-through intersectoral linkages. 
Nicholas Kaldor $(1966,1967)$ elaborated upon the ideas of Smith and Young to explain growth and divergence among nations. He found that there is a strong causal positive relationship between the growth of manufacturing output and the growth of GDP; ${ }^{6}$ and also between the rate at which the manufacturing sector expands and the growth of productivity outside of the manufacturing sector because of diminishing returns in agriculture and in many petty services that supply labor to the industrial sector. Indeed, if the marginal product of labor is below the average product (productivity) in these sectors, their productivity will rise as employment is depleted. Moreover, as surplus labor becomes exhausted in the nonmanufacturing sectors, and productivity levels tend to equalize across sectors, the degree of overall productivity growth induced by manufacturing output growth is likely to diminish. This is why countries' growth rates tend to be fastest in the take-off stage of development and overall GDP growth will tend to slow up as the scope for absorbing labor from diminishing returns activities dries up. Box 3 provides a summary of the empirical literature.

\section{Box 3: The Literature on the Engine of Growth Hypothesis}

The existing literature indicates that manufacturing was a driver of growth of the developed countries during 1950-73, and in recent years in the developing countries. In the latter, the contribution of the service sector has become more relevant and the share of services in GDP is now well above 70\% in the most advanced economies. The table below summarizes some of the recent work on the engine of growth hypothesis, which the data tend to validate.

\begin{tabular}{|c|c|c|}
\hline Authors & What They Did & What They Found \\
\hline \multirow[t]{2}{*}{ Hansen and Zhang (1996) } & $\begin{array}{l}\text { Regressed GDP growth on } \\
\text { manufacturing growth, using data on } \\
28 \text { Chinese regions for 1965-1991 }\end{array}$ & $\begin{array}{l}\text { Regression yields a very high fit, } 0.67 \\
\text { Slope of } 0.56 \text {, indicating that a region with } \\
\text { manufacturing output growth one } \\
\text { percentage point above the average for all } \\
\text { regions will grow } 0.56 \% \text { above the average } \\
\text { of all regions }\end{array}$ \\
\hline & $\begin{array}{l}\text { Also regressed productivity in } \\
\text { manufacturing on manufacturing } \\
\text { growth (i.e., Verdoorn's Law) }\end{array}$ & $\begin{array}{l}\text { Slope of } 0.71 \text {, indicating that, on average, a } 1 \% \\
\text { difference in the growth rate of output } \\
\text { induces a } 0.71 \text { percentage point difference in } \\
\text { the growth rate of labor productivity. This is a } \\
\text { very high coefficient that reflects large } \\
\text { economies of scale reaped during the early } \\
\text { stages of development. }\end{array}$ \\
\hline Fagerberg and Verspagen (1999) & $\begin{array}{l}\text { Regressed real GDP growth on } \\
\text { growth rates of manufacturing }\end{array}$ & $\begin{array}{l}\text { Corroborated engine of growth hypothesis } \\
\text { for Asia and Latin America } \\
\text { No significant effect on manufacturing in } \\
\text { the advanced economies }\end{array}$ \\
\hline Fagerberg and Verspagen (2002) & $\begin{array}{l}\text { Examined the impact of shares of } \\
\text { manufacturing and services in three } \\
\text { periods: 1966-1972, 1973-1983, } \\
\text { 1984-1995, using a sample of } 76 \\
\text { countries }\end{array}$ & $\begin{array}{l}\text { Manufacturing has much more positive } \\
\text { effects before } 1973 \text { than after. } \\
\text { After 1973, ICT technologies started to } \\
\text { become more important as a source of } \\
\text { productivity growth, especially in the } \\
\text { 1990s. Many of these technologies are } \\
\text { within the domain of services. }\end{array}$ \\
\hline
\end{tabular}

continued on next page

6 It may be argued that this is a spurious correlation to the extent that industrial output is a sizable share of GDP; hence the 'same' variable appears on both sides of the equation. This can be solved by: (i) regressing the growth of output on the difference between industrial and nonindustrial output growth; or by (ii) regressing nonindustrial output growth on industrial output growth. 
Box 3 continued

\begin{tabular}{|c|c|c|}
\hline Authors & What They Did & What They Found \\
\hline Felipe et al. (2009) & $\begin{array}{l}17 \text { Asian developing countries for } \\
1980-2004 \\
\text { Regression of nonmanufacturing } \\
\text { output on manufacturing output; } \\
\text { and accounting decompositions of } \\
\text { the growth rate of labor productivity }\end{array}$ & $\begin{array}{l}\text { Both industry and services appear to have } \\
\text { acted as engines of growth in Asia. } \\
\text { Manufacturing is subject to strong increasing } \\
\text { returns to scale. They also found high } \\
\text { increasing returns in services, which appear to } \\
\text { be a very dynamic sector. } \\
\text { Services appear to have contributed largely to } \\
\text { growth as they drag employment from the } \\
\text { less productive agricultural sector. }\end{array}$ \\
\hline Rodrik (2009) & $\begin{array}{l}\text { Regressed 5-year period growth } \\
\text { rates of GDP on shares of overall } \\
\text { industry in GDP in the initial year }\end{array}$ & $\begin{array}{l}\text { Significant positive relationship, ascribed to } \\
\text { the structural bonus argument: transition into } \\
\text { modern activities acts as an engine of growth }\end{array}$ \\
\hline Timmer and de Vries (2009) & $\begin{array}{l}\text { Using growth accounting, they } \\
\text { calculated the proportion of } \\
\text { aggregate growth accounted for by } \\
\text { different sectors in periods of growth } \\
\text { accelerations, in periods of normal } \\
\text { growth, and in periods of growth } \\
\text { deceleration }\end{array}$ & $\begin{array}{l}\text { Increasing importance of services in Asia } \\
\text { and Latin America } \\
\text { In periods of normal growth, they find that } \\
\text { manufacturing contributed the most. In } \\
\text { periods of growth acceleration, it is } \\
\text { services, though manufacturing contributes } \\
\text { positively. }\end{array}$ \\
\hline \multirow[b]{2}{*}{ Kathuria and Raj (2009) } & \multirow[t]{4}{*}{$\begin{array}{l}\text { Work on India. Somewhat } \\
\text { contradictory results }\end{array}$} & $\begin{array}{l}\text { Work on India. Somewhat contradictory } \\
\text { results }\end{array}$ \\
\hline & & $\begin{array}{l}\text { Hypothesis is examined at regional level for } \\
\text { recent years. They conclude that more } \\
\text { industrialized regions grow more rapidly. }\end{array}$ \\
\hline \multirow{2}{*}{$\begin{array}{l}\text { Thomas (2009) } \\
\text { Chakravarty and Mitra (2009) }\end{array}$} & & $\begin{array}{l}\text { Services have been the prime driver of } \\
\text { growth in India since } 1990 .\end{array}$ \\
\hline & & $\begin{array}{l}\text { Manufacturing is clearly a determinant of } \\
\text { overall growth. Construction and services turn } \\
\text { out to be important for manufacturing growth. }\end{array}$ \\
\hline Szirmai (2012) & $\begin{array}{l}\text { Tested the hypothesis for a group of } \\
\text { advanced, Asian and Latin American } \\
\text { countries } \\
\text { Focused on capital intensity, growth } \\
\text { of output, and growth of labor } \\
\text { productivity }\end{array}$ & $\begin{array}{l}\text { Hypothesis is, in general, supported, but in } \\
\text { some periods, capital intensity in services } \\
\text { and industry turns out to be higher than in } \\
\text { manufacturing. } \\
\text { In the advanced economies productivity } \\
\text { growth in agriculture is more rapid than in } \\
\text { manufacturing. }\end{array}$ \\
\hline Szirmai and Verspagen (2015) & $\begin{array}{l}\text { Regressed 5-year period of GDP per } \\
\text { capita growth on shares of } \\
\text { manufacturing and services, and } \\
\text { controls (e.g., GDP per capita } \\
\text { relative to that of the US, } \\
\text { education), for } 88 \text { countries, for } \\
\text { 1950-2005, and subperiods (1950- } \\
\text { 1970; 1970-1990; and 1990-2005) }\end{array}$ & $\begin{array}{l}\text { Whole period: moderate positive impact of } \\
\text { manufacturing on growth. No effect from services } \\
\text { By subperiods: manufacturing has an effect } \\
\text { only during 1970-1990. Services also has a } \\
\text { positive impact during this period. } \\
\text { Significant interaction effect of manufacturing } \\
\text { with education and income gaps: there is a } \\
\text { positive effect of manufacturing on growth in } \\
\text { developing countries with an educated workforce. } \\
\text { Since 1990, manufacturing has become a } \\
\text { somewhat more difficult route to growth. }\end{array}$ \\
\hline
\end{tabular}

GDP = gross domestic product, ICT = information and communication technology, US = United States. Source: Author's compilation. 
Figure 5 shows the scatter plot of the annual growth rate of output vis-à-vis the absolute change in the share of manufacturing in total output for the 1970s-2010s. The figure documents the positive correlation between both variables. The regression includes a dummy variable that tests whether Asian countries are different. There is evidence that they are. For the non-Asian sample, the slope of 0.047 indicates that a country that registered an increase by 1 percentage point in the manufacturing share above the average of all countries ( -3.09 percentage points) will register a GDP growth of 0.047 percentage points above the average. For the Asian countries, the slope is $0.089(0.047+0.042)$. Among the countries in the first quadrant with the highest increases in the manufacturing share and in the output growth rate are Bangladesh, Bhutan, Cambodia, Malaysia, the Republic of Korea, and Thailand.

\section{Figure 5: Output Growth versus Change in Manufacturing Output Share}

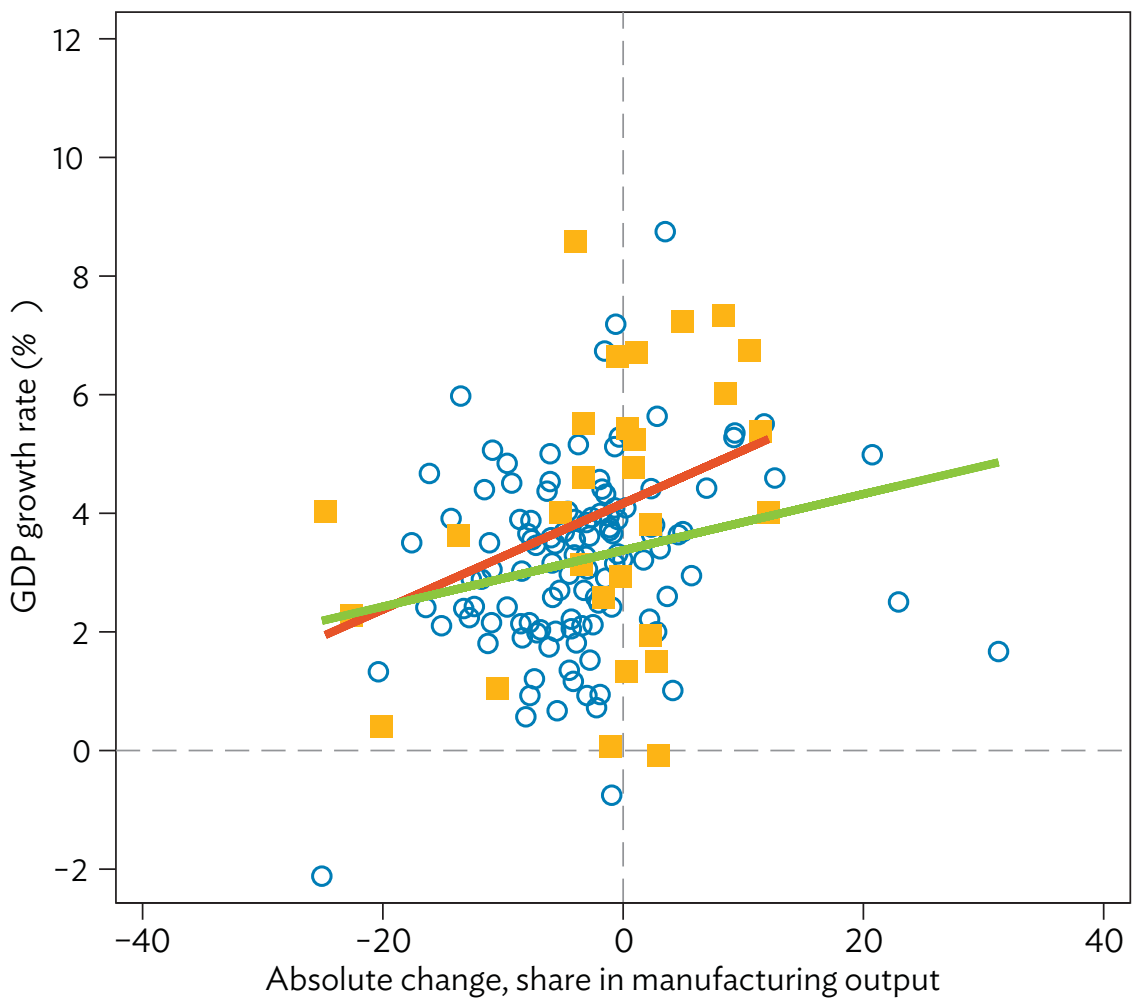

(1970s-2010s)

Developing Asia $\quad$ Rest of the world

GDP = gross domestic product.

Note: The initial and final years for each country vary with availability of data. Period covered is anywhere between 1970 and 2016. Changes in shares are measured in percentage points.

Source: Author's estimates based on data from the World Bank's World Development Indicators online database (accessed 18 January 2018) 
Likewise, regressions of GDP growth on industrial growth tend to yield relatively high fits, with a slope of less than unity, indicating that the greater the excess of industrial growth over GDP growth, the faster GDP growth will be. For example, a regression with data for 131 economies for the period 2000$2005\left(R^{2}=0.50\right)$, yields a slope of 0.39 , which indicates that a country with an industrial growth 1 percentage point above the average of all countries (about 4.5\%) will have a GDP growth of 0.39 percentage points above the average. However, this regression may just be a spurious correlation to the extent that industrial output is a sizable share of GDP (hence the 'same' variable appears on both sides of the equation). This is solved by regressing nonmanufacturing output growth on manufacturing output growth. Results are shown in Tables 1, 2, and 3 (individual country regressions for a sample of Asian countries). Table 1 for the complete period shows statistically significant coefficients $(\beta)$ for all large Asian economies (with $\beta<1$ as expected, except in the cases of Afghanistan and Maldives, where the coefficient is 2), with the notable exception of Viet Nam. Regression coefficients are statistically insignificant, even negative, for small economies like Cambodia, the Lao People's Democratic Republic, Mongolia, or the Pacific island countries. We also show the regression estimated until 1996, before the Asian Financial Crisis (AFC) (Table 2), and for the period afterwards, since 2000 (Table 3). The somewhat inexplicable results for $\mathrm{Viet} \mathrm{Nam}$ remain. We also note that the robust relationship between manufacturing and nonmanufacturing output growth broke down in Indonesia after the AFC; and that for Nepal, the relationship is statistically significant.

Table 1: Regression of Nonmanufacturing Growth on Manufacturing Growth, 1961-2016

$$
\widehat{Y^{N M}}=\alpha+\beta \widehat{Y^{M}}
$$

\begin{tabular}{|c|c|c|c|c|c|c|c|c|c|}
\hline & & $\begin{array}{c}\text { Mfg VA } \\
\text { Growth } \\
(\boldsymbol{\beta})\end{array}$ & $\mathrm{t}$-stat & $\begin{array}{l}\text { Constant } \\
(\alpha)\end{array}$ & t-stat & Obs & R-squared & $\begin{array}{l}\text { Start } \\
\text { Year }\end{array}$ & $\begin{array}{l}\text { End } \\
\text { Year }\end{array}$ \\
\hline (1) & Afghanistan & $2.012^{* * *}$ & $(3.252)$ & 2.244 & $(0.986)$ & 14 & 0.468 & 2003 & 2016 \\
\hline (2) & Armenia & $0.541^{* * *}$ & $(4.348)$ & 2.282 & (1.303) & 26 & 0.441 & 1991 & 2016 \\
\hline (3) & Azerbaijan & $0.380^{* *}$ & $(2.226)$ & $7.452^{* * *}$ & (3.021) & 24 & 0.184 & 1993 & 2016 \\
\hline (4) & Bangladesh & $0.126^{* * *}$ & (3.863) & $3.029^{* * *}$ & (6.523) & 56 & 0.216 & 1961 & 2016 \\
\hline (5) & Bhutan & $0.073^{* *}$ & $(2.347)$ & $6.487^{* * *}$ & $(7.622)$ & 36 & 0.139 & 1981 & 2016 \\
\hline (6) & Brunei Darussalam & $0.183^{*}$ & $(1.727)$ & $1.144^{* *}$ & $(2.475)$ & 27 & 0.107 & 1990 & 2016 \\
\hline (7) & Cambodia & -0.061 & $(-0.969)$ & $7.619^{* * *}$ & $(7.503)$ & 23 & 0.043 & 1994 & 2016 \\
\hline (8) & PRC & $0.229^{* * *}$ & (5.447) & $4.442^{* * *}$ & (5.754) & 51 & 0.377 & 1960 & 2010 \\
\hline (9) & Fiji & $0.175^{* * *}$ & (3.734) & $2.469^{* * *}$ & $(4.276)$ & 51 & 0.221 & 1966 & 2016 \\
\hline (10) & Hong Kong, China & $0.433^{* * *}$ & (3.573) & $4.792^{* * *}$ & $(7.655)$ & 16 & 0.477 & 2001 & 2016 \\
\hline (11) & India & $0.370^{* * *}$ & (3.675) & $2.956^{* * *}$ & $(4.032)$ & 56 & 0.200 & 1961 & 2016 \\
\hline (12) & Indonesia & $0.348^{* * *}$ & (5.569) & $2.366^{* * *}$ & $(4.009)$ & 56 & 0.365 & 1961 & 2016 \\
\hline (13) & Kazakhstan & $0.588^{* * *}$ & $(5.051)$ & $3.742^{* * *}$ & $(4.379)$ & 16 & 0.646 & 2001 & 2016 \\
\hline (14) & Kiribati & -0.004 & $(-0.174)$ & 1.000 & $(1.249)$ & 31 & 0.001 & 1983 & 2013 \\
\hline (15) & Korea, Rep. of & $0.388^{* * *}$ & (8.895) & $2.556^{* * *}$ & $(4.317)$ & 56 & 0.594 & 1961 & 2016 \\
\hline (16) & Kyrgyz Republic & $0.194^{* * *}$ & (3.541) & 1.720 & $(1.489)$ & 26 & 0.343 & 1991 & 2016 \\
\hline (17) & Lao PDR & $-0.141^{* *}$ & $(-2.294)$ & $8.470^{* * *}$ & (14.109) & 16 & 0.273 & 2001 & 2016 \\
\hline (18) & Malaysia & $0.342^{* * *}$ & $(7.765)$ & $3.016^{* * *}$ & $(6.253)$ & 46 & 0.578 & 1971 & 2016 \\
\hline
\end{tabular}


14 | ADB Economics Working Paper Series No. 549

Table 1 continued

\begin{tabular}{|c|c|c|c|c|c|c|c|c|c|}
\hline & & $\begin{array}{l}\text { Mfg VA } \\
\text { Growth } \\
(\boldsymbol{\beta})\end{array}$ & t-stat & $\begin{array}{l}\text { Constant } \\
(\alpha)\end{array}$ & t-stat & Obs & R-squared & $\begin{array}{l}\text { Start } \\
\text { Year }\end{array}$ & $\begin{array}{l}\text { End } \\
\text { Year }\end{array}$ \\
\hline (19) & Maldives & $2.165^{* * *}$ & $(7.962)$ & 3.447 & $(0.626)$ & 15 & 0.830 & 2002 & 2016 \\
\hline (20) & FSM & 0.016 & $(0.425)$ & 0.235 & $(0.330)$ & 20 & 0.010 & 1996 & 2015 \\
\hline (21) & Mongolia & 0.014 & $(0.182)$ & $6.451^{* * *}$ & $(5.814)$ & 21 & 0.002 & 1996 & 2016 \\
\hline$(22)$ & Myanmar & $0.149^{*}$ & $(1.782)$ & $6.083^{* * *}$ & (3.575) & 16 & 0.185 & 2001 & 2016 \\
\hline (23) & Nepal & 0.078 & $(1.608)$ & $3.707^{* * *}$ & $(8.350)$ & 43 & 0.059 & 1974 & 2016 \\
\hline (24) & Pakistan & $0.302^{* * *}$ & $(4.294)$ & $3.051^{* * *}$ & $(5.636)$ & 56 & 0.255 & 1961 & 2016 \\
\hline (25) & Palau & 0.038 & $(0.717)$ & 1.603 & $(1.180)$ & 16 & 0.035 & 2001 & 2016 \\
\hline$(26)$ & $\begin{array}{l}\text { Papua New } \\
\text { Guinea }\end{array}$ & $0.254^{* *}$ & $(2.136)$ & $2.997^{* * *}$ & (3.133) & 32 & 0.132 & 1981 & 2014 \\
\hline (27) & Philippines & $0.521^{* * *}$ & $(8.488)$ & $2.112^{* * *}$ & $(5.860)$ & 56 & 0.572 & 1961 & 2016 \\
\hline (28) & Samoa & 0.062 & $(0.985)$ & $4.041^{* * *}$ & (6.317) & 22 & 0.046 & 1995 & 2016 \\
\hline (29) & Singapore & $0.309^{* * *}$ & $(6.184)$ & $4.689^{* * *}$ & (8.083) & 56 & 0.415 & 1961 & 2016 \\
\hline (30) & Solomon Islands & 0.020 & $(0.243)$ & 2.590 & $(1.405)$ & 16 & 0.004 & 1991 & 2006 \\
\hline (31) & Sri Lanka & 0.099 & $(1.349)$ & $4.288^{* * *}$ & (8.937) & 55 & 0.033 & 1962 & 2016 \\
\hline (32) & Tajikistan & $0.604^{* * *}$ & $(4.574)$ & 1.786 & (1.088) & 28 & 0.446 & 1986 & 2013 \\
\hline (33) & Thailand & $0.415^{* * *}$ & $(7.651)$ & $2.292^{* * *}$ & $(4.254)$ & 56 & 0.520 & 1961 & 2016 \\
\hline (34) & Timor-Leste & -0.054 & $(-0.212)$ & $5.424^{* *}$ & $(2.586)$ & 15 & 0.003 & 2001 & 2015 \\
\hline (35) & Tonga & $-0.162^{* *}$ & $(-2.461)$ & $2.260^{* * *}$ & (4.889) & 35 & 0.155 & 1982 & 2016 \\
\hline (36) & Vanuatu & -0.004 & $(-0.111)$ & $2.835^{* * *}$ & (3.125) & 16 & 0.001 & 1999 & 2014 \\
\hline (37) & Viet Nam & $-0.144^{* * *}$ & $(-3.420)$ & $7.488^{* * *}$ & (15.615) & 31 & 0.287 & 1986 & 2016 \\
\hline
\end{tabular}

FSM = Federated States of Micronesia, Lao PDR = Lao People's Democratic Republic, PRC = People's Republic of China, VA = value added. Note: t-statistics in parentheses. ${ }^{* *} p<0.01,{ }^{* *} p<0.05,{ }^{*} p<0.1$.

Source: Author's estimates. 
Table 2: Regression of Nonmanufacturing Growth on Manufacturing Growth, 1961-1996

$$
\widehat{Y^{N M}}=\alpha+\beta \widehat{Y^{M}}
$$

\begin{tabular}{|c|c|c|c|c|c|c|c|}
\hline & & $\begin{array}{c}\text { Mfg VA } \\
\text { Growth } \\
(\boldsymbol{\beta})\end{array}$ & t-stat & $\begin{array}{l}\text { Constant } \\
\qquad(\alpha)\end{array}$ & t-stat & Obs & R-squared \\
\hline (1) & Bangladesh & $0.120^{* * *}$ & (3.054) & $2.372^{* * *}$ & (3.637) & 36 & 0.215 \\
\hline (2) & Bhutan & 0.070 & $(1.534)$ & $5.966^{* * *}$ & $(3.344)$ & 16 & 0.144 \\
\hline (3) & PRC & $0.229^{* * *}$ & $(5.827)$ & $3.733^{* * *}$ & $(4.575)$ & 36 & 0.500 \\
\hline (4) & Fiji & $0.188^{* * *}$ & $(3.314)$ & $2.971^{* * *}$ & $(3.563)$ & 31 & 0.275 \\
\hline (5) & India & $0.319^{* *}$ & $(2.460)$ & $2.495^{* * *}$ & $(2.775)$ & 36 & 0.151 \\
\hline (6) & Indonesia & $0.230^{* * *}$ & (3.624) & $3.222^{* * *}$ & $(4.582)$ & 36 & 0.279 \\
\hline (7) & Kiribati & -0.001 & $(-0.020)$ & 0.122 & $(0.081)$ & 14 & 0.000 \\
\hline (8) & Korea, Rep. of & $0.254^{* * *}$ & $(4.223)$ & $5.220^{* * *}$ & $(5.539)$ & 36 & 0.344 \\
\hline (9) & Malaysia & $0.334^{* * *}$ & $(4.054)$ & $3.097^{* * *}$ & $(2.984)$ & 26 & 0.406 \\
\hline$(10)$ & Nepal & 0.069 & $(0.951)$ & $3.536^{* * *}$ & $(4.098)$ & 23 & 0.041 \\
\hline (11) & Pakistan & $0.356^{* * *}$ & $(3.448)$ & $3.137^{* * *}$ & $(3.764)$ & 36 & 0.259 \\
\hline$(12)$ & Philippines & $0.570^{* * *}$ & $(7.596)$ & $1.639^{* * *}$ & (3.641) & 36 & 0.629 \\
\hline (13) & Papua New Guinea & 0.241 & $(1.540)$ & $3.434^{* *}$ & $(2.290)$ & 16 & 0.145 \\
\hline (14) & Singapore & $0.274^{* * *}$ & (3.693) & $5.693^{* * *}$ & $(6.259)$ & 36 & 0.286 \\
\hline$(15)$ & Sri Lanka & 0.058 & $(0.804)$ & $3.993^{* * *}$ & $(7.674)$ & 35 & 0.019 \\
\hline$(16)$ & Tajikistan & $0.643^{* *}$ & 4.087 & -3.541 & $(1.389)$ & 11 & 0.650 \\
\hline (17) & Thailand & $0.233^{* * *}$ & $(2.990)$ & $4.594^{* * *}$ & $(5.113)$ & 36 & 0.208 \\
\hline$(18)$ & Tonga & $-0.201^{* *}$ & $(-2.555)$ & $2.772^{* * *}$ & $(3.649)$ & 15 & 0.334 \\
\hline (19) & Viet Nam & -0.091 & $(-0.885)$ & $7.417^{* * *}$ & $(6.610)$ & 11 & 0.0801 \\
\hline
\end{tabular}

PRC $=$ People's Republic of China, $\mathrm{VA}=$ value added

Note: t-statistics in parentheses. ${ }^{* * *} p<0.01,{ }^{* *} p<0.05,{ }^{*} p<0.1$

Source: Author's estimates. 
16 | ADB Economics Working Paper Series No. 549

Table 3: Regression of Nonmanufacturing Growth on Manufacturing Growth, 2000-2016

$$
\widehat{Y^{N M}}=\alpha+\beta \widehat{Y^{M}}
$$

\begin{tabular}{|c|c|c|c|c|c|c|c|}
\hline & & $\begin{array}{c}\text { Mfg VA } \\
\text { Growth } \\
(\boldsymbol{\beta})\end{array}$ & $\mathrm{t}$-stat & $\begin{array}{c}\text { Constant } \\
(\boldsymbol{\alpha})\end{array}$ & t-stat & Obs & R-squared \\
\hline (1) & Afghanistan & $2.012^{* * *}$ & (3.252) & 2.244 & $(0.986)$ & 14 & 0.468 \\
\hline (2) & Armenia & 0.269 & $(0.969)$ & $5.333^{* *}$ & $(2.140)$ & 17 & 0.059 \\
\hline (3) & Azerbaijan & 0.035 & $(0.174)$ & $10.518^{* * *}$ & $(3.856)$ & 17 & 0.002 \\
\hline (4) & Bangladesh & $0.222^{* * *}$ & (3.414) & $3.554^{* * *}$ & $(6.406)$ & 17 & 0.437 \\
\hline (5) & Bhutan & $0.316^{* * *}$ & (3.510) & $5.183^{* * *}$ & (5.591) & 17 & 0.451 \\
\hline (6) & Brunei Darussalam & $0.240^{*}$ & (1.788) & $0.979^{*}$ & $(1.773)$ & 17 & 0.176 \\
\hline (7) & Cambodia & -0.044 & $(-0.624)$ & $7.552^{* * *}$ & $(7.036)$ & 17 & 0.025 \\
\hline (8) & PRC & 0.201 & $(1.045)$ & $7.869^{* * *}$ & $(3.597)$ & 11 & 0.108 \\
\hline (9) & Fiji & 0.049 & $(0.641)$ & $1.921^{* * *}$ & $(3.536)$ & 17 & 0.027 \\
\hline$(10)$ & Hong Kong, China & $0.433^{* * *}$ & (3.573) & $4.792^{* * *}$ & (7.655) & 16 & 0.477 \\
\hline (11) & India & $0.426^{* *}$ & $(2.753)$ & $3.571^{* *}$ & $(2.752)$ & 17 & 0.336 \\
\hline$(12)$ & Indonesia & -0.039 & $(-0.175)$ & $5.642^{* * *}$ & $(5.239)$ & 17 & 0.002 \\
\hline (13) & Kazakhstan & $0.588^{* * *}$ & (5.051) & $3.742^{* * *}$ & (4.379) & 16 & 0.646 \\
\hline (14) & Kiribati & -0.044 & $(-0.477)$ & $1.717^{*}$ & $(1.832)$ & 14 & 0.019 \\
\hline$(15)$ & Korea, Rep. of & $0.250^{* * *}$ & (3.967) & $2.090^{* * *}$ & $(4.482)$ & 17 & 0.512 \\
\hline$(16)$ & Kyrgyz Republic & $0.079^{* *}$ & $(2.307)$ & $4.564^{* * *}$ & $(7.887)$ & 17 & 0.262 \\
\hline$(17)$ & Lao PDR & $-0.141^{* *}$ & $(-2.294)$ & $8.470^{* * *}$ & (14.109) & 16 & 0.273 \\
\hline$(18)$ & Malaysia & $0.257^{* * *}$ & $(4.005)$ & $3.830^{* * *}$ & $(7.921)$ & 17 & 0.517 \\
\hline (19) & Maldives & $2.165^{* * *}$ & $(7.962)$ & 3.447 & $(0.626)$ & 15 & 0.830 \\
\hline (20) & FSM & 0.022 & $(0.614)$ & 0.628 & $(0.867)$ & 16 & 0.026 \\
\hline$(21)$ & Mongolia & -0.023 & $(-0.241)$ & $7.231^{* * *}$ & $(4.977)$ & 17 & 0.004 \\
\hline$(22)$ & Myanmar & $0.149^{*}$ & $(1.782)$ & $6.083^{* * *}$ & $(3.575)$ & 16 & 0.185 \\
\hline (23) & Nepal & $0.290^{* * *}$ & (3.694) & $3.723^{* * *}$ & (11.853) & 17 & 0.476 \\
\hline (24) & Pakistan & 0.139 & $(1.646)$ & $3.290^{* * *}$ & $(5.349)$ & 17 & 0.153 \\
\hline$(25)$ & Palau & 0.038 & $(0.717)$ & 1.603 & $(1.180)$ & 16 & 0.035 \\
\hline$(26)$ & Papua New Guinea & $0.380^{*}$ & $(1.867)$ & $3.461^{* *}$ & $(2.733)$ & 13 & 0.241 \\
\hline$(27)$ & Philippines & $0.247^{* *}$ & $(2.572)$ & $4.068^{* * *}$ & $(7.045)$ & 17 & 0.306 \\
\hline (28) & Samoa & 0.081 & $(1.310)$ & $3.587^{* * *}$ & (5.363) & 17 & 0.103 \\
\hline (29) & Singapore & $0.269^{* * *}$ & $(5.462)$ & $4.002^{* * *}$ & $(7.636)$ & 17 & 0.665 \\
\hline (30) & Solomon Islands & $0.741^{* *}$ & $(2.882)$ & 5.234 & (1.924) & 7 & 0.624 \\
\hline (31) & Sri Lanka & $0.515^{* *}$ & (2.791) & $3.732^{* * *}$ & $(4.118)$ & 17 & 0.342 \\
\hline$(32)$ & Tajikistan & $-0.235^{* *}$ & $(-2.605)$ & $10.380^{* * *}$ & (11.756) & 14 & 0.361 \\
\hline (33) & Thailand & $0.311^{* * *}$ & $(4.578)$ & $2.887^{* * *}$ & (7.283) & 17 & 0.583 \\
\hline (34) & Timor-Leste & -0.054 & $(-0.212)$ & $5.424^{* *}$ & $(2.586)$ & 15 & 0.003 \\
\hline (35) & Tonga & -0.003 & $(-0.020)$ & $1.690^{* *}$ & $(2.619)$ & 17 & 0.000 \\
\hline$(36)$ & Vanuatu & -0.004 & $(-0.106)$ & $3.009^{* * *}$ & $(3.160)$ & 15 & 0.001 \\
\hline (37) & Viet Nam & $-0.184^{* * *}$ & $(-6.828)$ & $7.684^{* * *}$ & $(24.180)$ & 17 & 0.757 \\
\hline
\end{tabular}

FSM = Federated States of Micronesia, Lao PDR = Lao People's Democratic Republic, PRC = People's Republic of China, VA = value added. Note: t-statistics in parentheses. ${ }^{* *} p<0.01,{ }^{* *} p<0.05,{ }^{*} p<0.1$.

Source: Author's estimates. 
We close this review of the empirical work on the engine of growth hypothesis by noting that some services do become more important at higher levels of per capita income. There is a new literature that argues that manufacturing is nevertheless important as a result of the intersectoral linkages between this sector and services. Service activities depend heavily on manufactured inputs. Manufacturing is also an important source of demand for modern intermediate service inputs such as financial services, transport and logistics, and business services (Park 2009). What is likely to be true is that the relations of dependence between manufacturing and services are symmetric: services depend more on manufacturing than vice versa. Also, the emergence of modern service activities depends on the structure of manufacturing. Some knowledge-intensive manufacturing sectors such as office and computing machinery, electrical apparatus or industrial chemicals are the main users of producer services (Guerrieri and Meliciani 2005).

\section{A. Understanding the Role of Manufacturing in Development: Two Important Questions}

There are two important questions to address to properly understand the role of manufacturing in development. First, what accounts for the fact that the faster manufacturing output grows relative to GDP the faster GDP seems to grow? And second, what determines the growth of the manufacturing sector in the first place? Or, what constraints manufacturing output growth?

On the first question, it is worth noting that since differences in growth rates are largely accounted for by differences in labor productivity growth rather than by differences in the growth rate of the labor force, there must be some relation between the growth of the manufacturing sector and productivity growth in the economy as a whole. There are two reasons that justify this. The first one is that whenever industrial production and output expand, labor resources are drawn from sectors that have open or disguised unemployment so that labor transfers into manufacturing do not cause a reduction in the output of these sectors, and productivity growth increases outside of manufacturing. A second reason is the existence of increasing returns within industry, both static and dynamic. Static returns result from the size and scale of production units, and are a characteristic of manufacturing. This occurs when, for example, output increases by a factor of more than 2 as the factors of production are doubled. Dynamic economies of scale are brought about by induced technical progress and learning by doing, itself the result of the expansion of production. Kaldor took this idea from the already mentioned work of Allyn Young (1928) and his work on increasing returns at the macroeconomic level, which result from the interaction between activities in the process of general industrial expansion. This is in contrast to agriculture, where productivity was seen as arising through labor-saving technical change and the movement of workers off the land.

On the second question, Kaldor argued that manufacturing output is not constrained by resources on the supply side; rather, a nascent industrial sector needs a market to sell. In the early stages of development, manufacturing growth draws on demand coming from agriculture. In this stage, agriculture is the largest 'external' (autonomous) sector, hence the importance of rising agricultural productivity to provide the purchasing power and growing market for industrial goods. Through time, however, the importance of agriculture as an autonomous market for industrial goods diminishes and exports take over in the later stages. In this sense, the capacity of exports to finance imports represents a constraint. A fast growth of exports and industrial output will tend to set up a virtuous circle of growth: fast export growth leads to fast output growth; fast export growth depends on competitiveness and the growth of world income; competitiveness depends on the relationship between wage growth and productivity growth; and fast productivity growth depends on fast output growth. In East Asia's successes (including the PRC), it is likely that agriculture did not provide the huge early market for 
manufactured goods that this theory confers it; rather, it was the world market that provided the proxy for domestic agricultural demand. This was because the share of agriculture fell very quickly (Felipe, Bayudan-Dacuycuy, and Lanzafame 2016).

Agriculture and export growth are the two fundamental sources of autonomous demand to match the leakages of income from the industrial sector of food imports from agriculture on the one hand, and imports from abroad on the other. A fast growth of exports and output may then set up a virtuous circle of growth with rapid export growth leading to rapid output growth, and rapid output growth leading to fast export growth through the favorable impact of output growth on competitiveness.

A significant part of the explanation behind Asia's fast growth experience is that these economies understood that, to get rich, they had to get into manufactures, which also offer the possibility to transform the economy by diversifying and upgrading it. Many developing countries have not been able to break into such virtuous circle, and this is the reason why polarization between countries exists. Indeed, the present north-south divide in the world economy has its origins in the fact that the north contains the first set of countries that industrialized, and only a handful of countries since have managed to challenge their industrial supremacy and therefore achieve their living standards. This point has been stressed in recent work by Rodrik (2010) discussing the PRC: If a nation wants to develop, it has to promote growth, which requires promoting manufacturing, which itself calls for expanding tradables.

\section{B. Export-Led Growth and Industrialization: Relaxing the Balance-of-Payments Constraint}

As noted above, Asia's industrialization since the 1960s has gone hand in hand with its increasing openness, in what has been referred to as the region's export-led growth (ELG) model. As also argued above, a fast growth of exports and industrial output set up a virtuous circle of growth in Asia that relaxed the initial balance-of-payments (BOP) constraint that most developing countries encounter, i.e., that to pay for necessary imports of capital goods, they have to export; otherwise they will end up running current account deficits.

Thirlwall (1979) and McCombie and Thirlwall (1994) have shown that the maximum growth rate a country can achieve without running into BOP problems is related to the growth rate of world income and to the income elasticities of demand for exports and imports. These last two variables prove to be fundamental to understand why the successful Asian countries progressed so fast: their economic transformation translated into exporting products with an increasing income elasticity of demand.

These authors have argued that disparities between countries in the income elasticities of demand for their exports and imports largely reflect differences in nonprice competitiveness, broadly defined. The message for a country whose export growth rate is relatively slow, and has a rather high import elasticity, is that the goods it produces are relatively unattractive. What is meant by the "characteristics" of the goods produced? Many manufacturing industries engage quite often in nonprice rather than price competition (McCombie and Thirlwall 1994). Nonprice competitiveness (branding and quality differentiation) encompasses all those factors other than price that affect consumers' choices, such as quality, reliability, speed of delivery, and extent and efficacy of the distribution network. The importance of nonprice competitiveness is that as per capita income grows, so increasingly does the demand for more sophisticated goods. For example, it is dubious that ex-Eastern bloc automobiles such as Skodas and Ladas would have ever made inroads into the markets of the advanced countries despite their exceptionally low prices. In the long run, in a world characterized by rapid product and process innovation, and where the rapid growth of demand is for increasingly sophisticated products, companies should not rely exclusively on price competition to maintain market share. This is exactly what Japanese 
companies like Toyota, Sony and many others did; what the Republic of Korea's Samsung, LG, and Hyundai did, and what the PRC's Lenovo and Huawei have also done.

If there are increasing returns to scale and induced productivity growth, export growth can set up a virtuous circle of growth that leads into center-periphery models of development which, on certain conditions, predict divergence between regions and countries in the world. ${ }^{7}$ This helps understand why countries that get into a virtuous circle of ELG do so well. In this model, the faster the growth of output the faster the growth of productivity; and the faster the latter the slower the growth of unit labor costs, and hence the faster the growth of exports and output. Once a country obtains a growth advantage, it will tend to sustain it. Suppose, for example, that an economy acquires an advantage in the production of goods with a high income elasticity of demand and achieves a growth rate above that of other economies. These goods could be technology-based activities like advanced machinery, chemicals, or automobiles, or consumer products such as an expensive ball pen or perfume (all manufactures). This means that productivity growth will be higher and the competitive advantage of the economy in these goods will be reinforced making it difficult for other countries to produce the same commodities, except through protection or exceptional industrial enterprise. In center-periphery models of growth and development, it is differences between the income elasticity characteristics of exports and imports which lie at the core of the problem for poor countries and at the heart of the success of rich countries: primary products tend to have an income elasticity of demand less than unity (Engel's Law) while most industrial products, largely produced by advanced economies, have an income elasticity greater than unity.

An important implication of this story is that growth rates between countries differ not because we observe countries in the process of divergence but because their equilibrium growth rates differ, and this is mainly associated with differences in the income elasticity of demand for their exports. Centreperiphery models à la Myrdal (1957) or Kaldor (1970) highlight the importance of the elasticities and contain mechanisms that will tend to perpetuate initial differences in income elasticities associated with 'inferior' industrial structures on the one hand, and 'superior' industrial structures on the other.

The relevance of nonprice competitiveness in the Asian context appears to be supported by the statistical analysis of Ang, Madsen, and Robertson (2015). These authors show that the spectacular productivity and export growth rates experienced by the Asian economies considered in their analysis (India; Japan; the PRC; the Republic of Korea; Singapore; and Taipei,China) during 1953-2010, were driven by innovation, in particular diversification (new product variety), an outcome of research and development (R\&D) in the intermediate goods producing sector. ${ }^{8}$ The coefficient of the (tradeweighted) income variable (proxy for nonprice competitiveness) is statistically significant and high,

7 To see this, consider what determines the growth of exports. Economists often argue that it depends on the difference between the growth of domestic prices and the growth of foreign prices (in a common currency), and on the growth of foreign income. The effect of these two variables on the growth of export demand depends on the elasticity of each, that is, on the price elasticity of demand for exports (negative), a proxy for price competitiveness; and on the income elasticity of demand for exports (positive), a proxy for nonprice competitiveness, e.g., characteristics of the goods produced and quality. This last parameter turns out to be key in the ELG explanation of Asia's growth. While the growth of foreign income, as well as the growth of foreign prices may be taken as exogenous, the growth of domestic prices is not. Typically, firms use a markup mechanism, where prices are set as labor costs per unit of output (unit labor cost) plus a percentage mark-up. This means that the growth of domestic prices equals the growth rate of the wage rate minus the growth rate of labor productivity (i.e., the growth rate of unit labor costs) plus the growth rate of the mark-up. The latter is partly dependent on the growth of output itself through static and dynamic returns to scale. The growth rate toward which countries tend (the equilibrium growth rate) in this model is positively related to the autonomous component of productivity growth, the rate of growth of foreign prices and the growth of world income; and negatively related to domestic wage growth and the increase in the mark-up.

8 The variables used to proxy technological competitiveness are: R\&D stock, patent stock, trademark stock, and product design stock. 
about 2 (interpreted as an elasticity). On the other hand, price competitiveness (measured by the price elasticities) was not a quantitatively important determinant of exports. They also find that innovation competitiveness has been less influential for export growth for the PRC and India. These two countries' export booms was more based on imitation and process innovation than on fundamental and innovation and product innovation.

The above means that, to grow fast, developing countries must, first of all, raise their constraints on demand, in particular, their BOP constraint. The question is how to do it. One possible option is to liberalize the economy and depreciate the currency. While trade liberalization may improve export performance, it may also lead to a faster growth of imports, which would worsen the balance of payments. Liberalization of the capital account is also fraught with problems without internal macroeconomic stability. Too high domestic interest rates will lead to capital inflows and overvalued currencies, which will damage the tradable sector. As far as devaluation is concerned, this does not raise a country's growth rate unless it is continuous. The exchange rate, however, is not an efficient instrument for structural transformation because it simply makes countries more competitive temporarily in the goods that cause the BOP problems in the first place. Countries can try and make their goods more price competitive by other means, but many of the goods developing countries produce (as a group), such as primary agriculture, raw materials and unsophisticated manufactures, are price inelastic. Likewise, we do not think that imposing import controls to reduce the income elasticity of demand for imports is the way to go as this can breed inefficiency.

Countries can also encourage long-term capital inflows (foreign direct investment [FDI]) to finance import growth in excess of export growth, but need to make extra efforts to ensure that technologies are transferred and that the goods produced put the country in a learning escalator. Most other types of inflow, apart from pure aid, involve debt-service repayments, and debt problems can arise if the inflows are not translated into improved export performance which can earn the foreign exchange to pay interest and amortization. Moreover, as the AFC of 1997-1998 clearly showed, financing evergrowing BOP deficits relative to GDP by increasing short-term capital flows is extremely dangerous. The current account of the balance of payments, and how it is financed, does matter for the real economy. Finally, even if the borrowing is invested in the tradable sector, foreign exchange is not guaranteed because the growth of exports is outside the control of the country. The export growth of developing countries depends largely on the health of the world economy.

The way to raise a country's BOP constraint on demand is by working on the nonprice characteristics of goods, such as their quality, technical sophistication, marketing, etc. The recent work on complexity by Hidalgo and Hausmann (2009), an idea that encompasses diversification at the country level and sophistication at the product level, shows that the structure of exports of many Asian countries shifted significantly during the last decades, from simple products like footwear and textiles to electronics, machinery, and chemicals (see also Felipe et al. 2012). We discuss this work in section $V$.

Country evidence shows that this shift is not easy and that virtually no country in the world has ever industrialized and moved up the development ladder without protection of one form of another. This brings us to the contentious issue of industrial policy in Asia. We do believe that there is an economic case for protection to alter the structure of production, induce growth-enhancing structural change, and to improve the balance of payments, but it needs to be implemented skillfully to avoid the protection of high-cost inefficient industries and the pursuit of rent-seeking. We return to this point in section IV. 


\section{The Industrialization Experiences of Japan and the Republic of Korea}

This subsection provides a brief summary of the industrialization experience of Asia's two most industrialized economies, Japan and the Republic of Korea.

\section{(1) Japan}

Japan was the first Asian economy that experienced the Industrial Revolution. Industrialization proceeded in three steps. The first one was the Meiji Restoration. The second one was the recovery after World War II (WWII). The third one was the period of high growth, starting in the 1960s. The Meiji Restoration (1868-1912) liquidated all forms of feudal economy (Maddison 1995, Chapter 2). At that point, Japan decided to embark on a total technical transformation that would wipe out the feudal economy and give it the power to resist the West. Meiji policy makers were determined to catch up to the economic, technological and military prowess of the West. They did this by importing the latter's foreign technologies and institutions, and assimilating them. For example, the government introduced, first, compulsory primary education, and then voluntary secondary and tertiary education. ${ }^{9}$ Also, students were dispatched to Europe and the US, and teachers were invited to return, in a determined effort to introduce western science and technology. The first steps in the industrialization process were taken under the guidance of the state, which built or financed shipyards, telegraph lines, railways, and armament works. The actual pioneer in the industrialization process was textiles and, for a long time, handicraft methods continued to be used alongside modern methods to produce Japan's industrial goods. Silk and exports of cotton yarn and cotton goods allowed Japan to do without much foreign investment in her drive toward industrialization. Japan was the first Asian country to reform agriculture, land could be bought and sold freely, people could produce any crop or commodity, and agricultural research was promoted. This led to an increase in agricultural productivity, which supported Japan's industrialization and its growing population. ${ }^{10}$ And this increase in productivity pushed farmers into manufacturing and service industries. ${ }^{11}$

Despite the great developmental efforts during the Meiji Restoration and the first part of the 20th century, Japan was not on the whole an economic star, and until the late 1950s the country was not well developed, e.g., its biggest export item was still silk and silk-related products. This came only

9 Japan already had a comprehensive system of education in the Tokugawa period (1603-1867), known as Terakoya. These were private educational institutions that taught writing and reading to the children of Japanese commoners.

10 Minami (1994, pp.70-73) argued that there are two theories about the relationship between early industrialization and agricultural growth in Japan: (i) first, the concurrent growth theory asserts that agricultural production was not expanding before industrialization began, and that the productivity of both labor and land were low. When industrialization started in about 1886 and until 1920, there was a period of rapid agrarian growth with the consequence that agriculture was able to support industrialization. In other words, agricultural and industrial expansion took place simultaneously, in contrast to what happened in Western countries, where significant agrarian growth occurred before, and hence it was a prerequisite for industrialization; (ii) second, the prerequisite theory argues that agricultural production had increased considerably prior to industrialization, and that Japan's agriculture underwent significant transformation between 1600 and 1850 . During this time, the productivity of land increased significantly and this provided the foundation for the modernization of Japan. Minami (1994, p.73) concludes that neither theory fits exactly the facts. In his words: "Agriculture had expanded considerably before industrialization began, and growth continued into the early period of industrialization; this was the key to its success. This fact is also true of the United Kingdom. According to recent studies, progress in agriculture began earlier than had been thought, and continued longer. The fact that agricultural and industrial improvement overlapped one another brought about the success of the industrial improvement."

11 With the modernization of agriculture, this sector became dependent on industry for farm machines, fertilizer, and agricultural chemicals. 
after WWII. ${ }^{12}$ Further land reform was undertaken during 1947-1948. Other factors that contributed significantly to Japan's recovery were: (i) The Korean War (1950-1953); (ii) increase in competition by breaking up the old zaibatsu and legalization of trade unions; (iii) the pursuit of economic growth as the national objective; (iv) the demilitarization and the reduction of defense spending; ( $v$ ) the introduction of certain employment practices (e.g., lifetime employment) that helped to maintain stable management-labor relations; (vi) Japan's capacity to absorb and assimilate advanced technologies from the West; (vii); the prewar experience of the 1930s and 1940s, when Japan developed the management tools of its developmental state (Johnson 1982); and (viii) the role of the government, in particular planning by the Ministry of International Trade and Industry (MITI) and the use of industrial policies, including policies that encouraged investment, e.g., low interest rates, and the emphasis on promoting exports-undervaluation of the yen (see below the discussion on industrial policies).

The recovery period that started in about 1950 was set on the basis of a plan drawn up to give priority in recovery to the basic industries, namely steel, coal, fertilizer, gas, cement, and railroads. The idea was to increase linkage effects by devoting resources to coal production, key to manufacture iron and steel; and steel materials would be used to increase coal production. However, the program was misguided insofar as existing coal mines were obsolete and skilled miners were in short supply. The situation in the cement sector was no better. In 1950, the Japanese coal industry turned to Europe for technology and introduced Germany's Kappe method of coal mining. The steel industry recovered very slowly as a consequence of the fact that the newest of the nation's furnaces were designated for reparations and most chief executives were purged. The result is that the strategy of economic recovery, based on coal and steel, had to be discontinued and priority shifted to shipping, electric power, and transportation. Shipping had initially been designated also an industry for reparation. However, the Occupation policy started to change and as the Cold War progressed, the US decided to use Japan and Germany as factories to help rehabilitate their respective neighboring countries.

The outbreak of the Korean War (1950-1953) helped galvanize the Japanese economy as virtually all branches of industry benefited from "special procurements." It provided a springboard for rapid recovery in the 1950s and for rapid growth in the 1960s. The Korean War also revitalized the Japanese steel industry. Japan imported new equipment to expand capacity and improve quality. ${ }^{13}$ Technology transfers were very liberal at the time and Japan was very wise in importing technology (e.g., strip mill; basic oxygen steelmaking process, known as the Linz-Donawitz [LD] process). ${ }^{14}$ These transfers brought in improvements not just directly to the steel industry but also to all those industries that used steel, such as cars, small electric appliances, and other durable consumer goods. During the 1970s, Japan also took advantage of technology transfers in electronics, high-polymer chemicals, and atomic energy.

After recovery from the war during the 1950s, Japan entered a period of very fast growth in 1960. Japan reached upper-middle income status in 1968 and high income in 1977. Japan's fast growth and

12 Hayashi and Prescott (2008) argue that the Japanese miracle did not take place before WWII as a result of a crucial barrier that prevented the movement of agricultural labor. This barrier was the fact that the prewar patriarchal system forced the son designated as heir to stay in agriculture.

13 The Korean War had an enormous positive impact on the Japanese economy. During the first year (1950), the 'special procurements' reached $\$ 340$ million. This was enough to "clear all the backlogs in the manufacturing industries that had been caused by the Dodge Line policy. Goods and materials for the use by the UN forces ranged from locomotives, rails, trucks, steel materials, iron posts, electric wire, barbed wire, and other heavy-industry products to chemicals, processed foodstuffs, clothing, and medicines. The procurements reached into all branches of Japanese industry, three branches alone-metals, machinery, and textiles-accounted for 70 per cent of the special procurements." (Hayashi 1990, pp.11-12).

14 See also Aoki et al. (2011). 
catch-up is explained by three types of factors: (i) its macroeconomic model, the virtuous circle between investment, exports, and manufacturing upgrading; (ii) it became a nation driven by technical progress; and (iii) the continual use of industrial policies that supported growth in the context of a developmental state.

First, at the macroeconomic level, Japan achieved high rates of savings and investment. Returns to savers were squeezed, and those returns were shifted to the industrial companies that needed capital. Overall, this created a virtuous circle between investment (which grew faster than GDP) and exports (Japan ran export surpluses), especially export-oriented manufacturing. Likewise, Japan became a manufacturing powerhouse that soon would rival the US and Europe. The result was that between 1960 and 1973, Japan sustained a 10\% per year average growth rate, and thus closed a significant share of the GDP gap. This was the highest sustained rate of growth of a large real economy in the previous history of the world.

The second fact that explains Japan's high growth rates is that it understood the importance of fast technical progress, science, and technology. To expedite its catch-up, Japan used technology transfers right from the end of the war. But if transfers during the 1950s aimed at recovering prewar production levels, the transfers in the 1960s aimed at preventing an influx of foreign goods and to strengthen the country's position in what it was thought to be imminent, namely, an international commercial war. Hence, the large production scale that Japan was building aimed not only at satisfying domestic demand but also at exporting. Moreover, if during the Meiji period, Japan became an industrialized country under slogans such as "promotion of industry," "prevention of imports," and "strong army," in the 1960s, the objective was to nonmilitary: to transform the production system into automate high-speed mass production. During the 1960s, Japan's technology transfers from the US and Europe, were in sectors such as automobiles, small electric appliances, and petrochemicals As a result, products in these sectors began to be mass-produced as domestic products and became highly competitive with foreign goods in Japan's home market. During the 1970s, the range of technology transfers extended to electronics, high-polymer chemicals, and atomic energy. Except in atomic energy, and in particular in electronics, Japan followed a slow and painful learning/assimilating process with the objective to overtake the advanced economies (Hayashi 1990, pp.17-22). ${ }^{15}$ But it would be a misunderstanding to think that Japanese achievements were due solely to technology transfers from the advanced economies. Technological progress in postwar Japan was remarkable: machines were renewed every decade and so were factory layouts. Apart from the need to recover from its heavy war losses, Japanese industry made sound efforts toward creating innovative designs of the entire manufacturing process, from factory layout to factory location. This led to huge productivity increases that allowed wage increases. During this period, Japan also achieved full employment. To achieve all this, Japan needed to open new markets to absorb the increase in productivity.

15 By the mid-1960s, Yawata steel was already asked for technological advice. 
Third and final, Japan continued using industrial policies and its credit-based financial system to support growth. Banks are institutions equipped to solve incentive and informational problems inherent in market economies, and can contribute to promoting long-term growth.

Overall, by the early-mid 2000s, Japan had managed to have the most complex export basket in the world (Table 4), with complexity defined as a combination of how diversified a country is (measured by the number of products exported with comparative advantage) and how unique the country's export basket is (measured by the number of countries that export a product) -recall the discussion about capabilities and the concept of complexity above (Felipe et al. 2012). The data set used to generate Table 4 contains 5,107 products for 124 countries. Almost $40 \%$ of Japan's exports belong to the most (i.e., the top 850) complex products (chemicals, machinery and electrical products, plastics). And Table 5 shows that Japan is one of the top five exporters in nine of the top 10 most complex products exported in the world.

Table 4: Share in Country's Total Exports, by Product Complexity, Average 2001-2007

\begin{tabular}{|c|c|c|c|c|c|c|c|c|}
\hline \multirow[b]{2}{*}{ Country } & \multirow[b]{2}{*}{ Rank } & \multicolumn{7}{|c|}{ Product Complexity Level $(1=$ highest; 6 = lowest $)$} \\
\hline & & 1 & Top 100 & 2 & 3 & 4 & 5 & 6 \\
\hline Japan & 1 & 39.7 & 10.0 & 19.0 & 21.9 & 11.4 & 6.6 & 1.5 \\
\hline Germany & 2 & 39.6 & 7.9 & 24.5 & 16.0 & 10.9 & 5.6 & 3.4 \\
\hline United States & 6 & 28.1 & 7.2 & 21.5 & 22.8 & 12.9 & 9.4 & 5.2 \\
\hline France & 10 & 26.2 & 3.2 & 22.3 & 22.0 & 16.1 & 7.5 & 5.9 \\
\hline Singapore & 19 & 14.3 & 1.5 & 14.0 & 39.2 & 11.1 & 4.2 & 17.2 \\
\hline Korea, Rep. of & 21 & 17.7 & 2.2 & 18.9 & 32.5 & 14.6 & 8.3 & 8.0 \\
\hline Malaysia & 38 & 4.7 & 0.5 & 14.3 & 38.6 & 15.6 & 7.4 & 19.4 \\
\hline India & 49 & 8.1 & 0.7 & 9.2 & 8.3 & 9.4 & 30.4 & 34.7 \\
\hline PRC & 50 & 5.7 & 0.5 & 13.9 & 20.7 & 19.5 & 15.6 & 24.5 \\
\hline Thailand & 59 & 6.8 & 0.5 & 9.1 & 31.3 & 16.2 & 11.5 & 25.1 \\
\hline Philippines & 74 & 3.3 & 0.3 & 7.3 & 49.2 & 20.5 & 6.4 & 13.4 \\
\hline Indonesia & 76 & 3.1 & 0.4 & 5.3 & 12.9 & 15.2 & 14.4 & 49.1 \\
\hline Viet Nam & 98 & 1.8 & 0.2 & 3.0 & 4.2 & 7.3 & 14.2 & 69.6 \\
\hline Pakistan & 101 & 0.7 & 0.1 & 2.2 & 2.2 & 3.5 & 11.9 & 79.6 \\
\hline
\end{tabular}

PRC $=$ People's Republic of China

Note: Number of products in the analysis is 5,107 and the number of countries is 124 .

Source: Table 6 of Felipe, Jesus, Utsav Kumar, Arnelyn Abdon, and Marife Bacate. 2012. "Product Complexity and Economic Development." Structural Change and Economic Dynamics 23 (1): 36-68. 
Table 5: The 10 Most Complex Products and Their Exporters

\begin{tabular}{|c|c|c|c|c|}
\hline Commodity Description (HS2 group) & Top Five Exporters & $\begin{array}{c}\text { GDP per } \\
\text { Capita }\end{array}$ & $\mathrm{RCA}$ & $\begin{array}{l}\text { Export } \\
\text { Share }\end{array}$ \\
\hline \multirow{5}{*}{$\begin{array}{l}\text { (1) Other cyclic hydrocarbons: Cumene (organic } \\
\text { chemicals) }\end{array}$} & The Netherlands & 34,768 & 14.3 & 48.4 \\
\hline & United States & 40,977 & 2.3 & 23.2 \\
\hline & Japan & 29,849 & 2.5 & 16.3 \\
\hline & Germany & 31,524 & 0.7 & 6.2 \\
\hline & United Kingdom & 31,664 & 0.5 & 2.2 \\
\hline \multirow{5}{*}{$\begin{array}{l}\text { (2) Metalworking machine-tools/ultrasonic machine- } \\
\text { tools: for dry-etching patterns on semiconductor } \\
\text { materials (nuclear reactors, boilers, machinery, etc.) }\end{array}$} & United States & 40,977 & 5.8 & 57.1 \\
\hline & Japan & 29,849 & 4.4 & 29.8 \\
\hline & The Netherlands & 34,768 & 0.9 & 3.1 \\
\hline & Malaysia & 11,350 & 1.6 & 2.9 \\
\hline & United Kingdom & 31,664 & 0.6 & 2.2 \\
\hline \multirow{5}{*}{$\begin{array}{l}\text { (3) Particle accelerators and parts thereof, nes: ion } \\
\text { implanters for doping semiconductor materials } \\
\text { (electrical, electronic equipment) }\end{array}$} & United States & 40,977 & 6.3 & 61.6 \\
\hline & United Kingdom & 31,664 & 5.8 & 21.8 \\
\hline & Japan & 29,849 & 1.5 & 10.1 \\
\hline & France & 30,411 & 0.5 & 2.0 \\
\hline & The Netherlands & 34,768 & 0.2 & 0.8 \\
\hline \multirow{5}{*}{ (4) Methacrylic acid, salts (organic chemicals) } & Germany & 31,524 & 3.4 & 31.6 \\
\hline & United States & 40,977 & 2.1 & 20.5 \\
\hline & Japan & 29,849 & 2.8 & 18.9 \\
\hline & Belgium & 31,695 & 3.4 & 8.0 \\
\hline & United Kingdom & 31,664 & 2.0 & 7.3 \\
\hline \multirow{5}{*}{$\begin{array}{l}\text { (5) Carbide tool tips, etc.: tool plates/tips/etc., } \\
\text { sintered metal carbide and cermets (tools, } \\
\text { implements, cutlery, etc. of base metal) }\end{array}$} & Sweden & 31,506 & 11.9 & 15.4 \\
\hline & Germany & 31,524 & 1.6 & 14.7 \\
\hline & Israel & 22,915 & 26.9 & 12.4 \\
\hline & Japan & 29,849 & 1.6 & 10.9 \\
\hline & United States & 40,977 & 0.8 & 7.8 \\
\hline \multirow{5}{*}{$\begin{array}{l}\text { (6) Photo, cine laboratories equipment, nes; screens } \\
\text { for projectors: direct write-on-wafer apparatus } \\
\text { (optical, photo, technical, medical, etc. apparatus) }\end{array}$} & Japan & 29,849 & 5.3 & 35.0 \\
\hline & Germany & 31,524 & 1.8 & 16.0 \\
\hline & The Netherlands & 34,768 & 4.2 & 14.5 \\
\hline & United Kingdom & 31,664 & 2.4 & 9.3 \\
\hline & United States & 40,977 & 0.8 & 8.7 \\
\hline \multirow{5}{*}{$\begin{array}{l}\text { (7) Other inorganic esters: hexamethylenediamine, } \\
\text { its salts (organic chemicals) }\end{array}$} & France & 30,411 & 8.6 & 39.2 \\
\hline & United States & 40,977 & 2.6 & 25.3 \\
\hline & Belgium & 31,695 & 6.4 & 15.3 \\
\hline & United Kingdom & 31,664 & 4.4 & 15.2 \\
\hline & Germany & 31,524 & 0.3 & 2.9 \\
\hline \multirow{5}{*}{$\begin{array}{l}\text { (8) Other electronic measuring, controlling, etc. } \\
\text { apparatus: instruments nes using optical radiations } \\
\text { (UV, visible, IR) (optical, photo, technical, medical, } \\
\text { etc. apparatus) }\end{array}$} & United States & 40,977 & 2.7 & 26.6 \\
\hline & Germany & 31,524 & 1.9 & 17.4 \\
\hline & Japan & 29,849 & 2.5 & 16.5 \\
\hline & United Kingdom & 31,664 & 1.4 & 5.2 \\
\hline & Ireland & 37,299 & 3.4 & 4.7 \\
\hline \multirow{5}{*}{$\begin{array}{l}\text { (9) Other machinery, mechanical appliances having } \\
\text { individual functions: laser, light, and photon beam } \\
\text { process machine tools (nuclear reactors, boilers, } \\
\text { machinery, etc.) }\end{array}$} & Switzerland & 35,648 & 17.4 & 24.2 \\
\hline & Japan & 29,849 & 3.5 & 23.1 \\
\hline & Germany & 31,524 & 1.8 & 17.0 \\
\hline & United States & 40,977 & 1.5 & 15.2 \\
\hline & Italy & 28,277 & 1.2 & 4.5 \\
\hline \multirow{5}{*}{$\begin{array}{l}\text { (10) Sheet, plates, rolled of thickness } 4.75 \mathrm{~mm} \text { plus, } \\
\text { of iron or steel or other alloy steel: cold rolled alloy- } \\
\text { steel nes, not further worked (cold-reduced), <600 } \\
\text { mm wide (iron and steel) }\end{array}$} & Germany & 31,524 & 2.9 & 26.8 \\
\hline & Japan & 29,849 & 3.3 & 22.0 \\
\hline & France & 30,411 & 3.3 & 14.9 \\
\hline & Belgium & 31,695 & 2.4 & 5.9 \\
\hline & United States & 40,977 & 0.6 & 5.8 \\
\hline
\end{tabular}

$\mathrm{GDP}=$ gross domestic product, $\mathrm{HS}=$ harmonized system, $\mathrm{mm}=$ millimeter, nes = not elsewhere specified, $\mathrm{RCA}$ = revealed comparative advantage. Note: Number of products in the analysis is 5,107 and the number of countries is 124 . Share of exports in total world exports. GDP per capita, RCA, and export shares reported are averages for 2001-2007. GDP per capita (in 2005 PPP\$) from World Development Indicators is used. Export shares are based on data for all HS 6-digit products and all countries.

Source: Table 2 of Felipe, Jesus, Utsav Kumar, Arnelyn Abdon, and Marife Bacate. 2012. "Product Complexity and Economic Development.” Structural Change and Economic Dynamics 23 (1): 36-68. 


\section{(2) Republic of Korea}

The Republic of Korea's modernization did not start until after WWII, and the period between the end of the war and the early 1960s was one of transition. One of the most significant achievements of this period was land reform, undertaken between 1949 and 1952. The country concentrated on the production of light manufactures (wood, leather, rubber, paper) and nondurable consumers (food, beverages, tobacco, textiles, clothing, footwear, cement). This was supported by a protectionist trade regime, foreign exchange controls and import restrictions. During 1953-1962, the country achieved an average growth rate of 4.2\% per annum. This may seem low and it is tempting to blame the import substitution regime (Tan 1999, p.81). However, this overlooks the fact that during this period, there was significant rebuilding and expansion of the private sector (in fact this period saw the building of a market economy). Indeed, the divestment of state-owned enterprises gave rise to capitalist groups that eventually would become Samsung, Hyundai, and Hanjin in the 1960s and 1970s, so-called chaebols (a small number of very large family-owned and run firms and business conglomerates with large market shares in many different industries).

In 1961, the Korean army took charge through a coup led by general Park Chung Hee, who was elected president in 1963, following the return to civilian government. He was in power until 1979. In 1962, still $69 \%$ of Korean workers were employed in agriculture. Park transformed the country into a developmental state that followed the steps of the latecomer industrializers. He quickly reversed previous economic policies (e.g., import substitution) and transformed the country into an export-led industrial power following the Japanese model, i.e., channeling funds to the industrial sector. As we explain below, between the 1960s and the 1980s, the Republic of Korea's industrial policy followed Japan's steps, but in a much more intense way. While substantial US aid during the 1950s and early 1960s facilitated accumulation and industrialization, this declined during the 1960s, with the consequence that the Republic of Korea was forced to export. ${ }^{16}$ Unlike Malaysia, the Republic of Korea could not rely on exports of primary products to finance its imports. It became obvious that it needed a different model. During the developmental decades after 1961, the government again turned heavy interventionist, and created a particular business-state relationship that made the country neither a free-market economy nor a centrally planned economy. Jung (1994) referred to it as a regulated market economy.

The Republic of Korea's state intervention after 1961 had the objective to build an independent economy and to achieve industrial upgrading by transferring labor from low-productivity sectors into highproductivity sectors. This was clearly institutionalized in the 1970s with the heavy and chemical industries ( $\mathrm{HCl}$ ) program of 1973 (see below); and also in the 1980s (Industrial Development Law of 1986) to nurture sunrise industries, to restructure sunset industries, or to provide assistance to critical industries. The institutionalization of growth as a prime objective gave reformist technocrats tremendous political space and power and they were allowed to use a wide range of policy instruments. The Park system had credibility to enforce reforms. Why? This came only partly from the fact that his was a military regime. ${ }^{17}$ The more important reasons are first, the lack of a strong, entrenched, class interests (rural based or otherwise). This explains the form of state intervention in the Republic of Korea. ${ }^{18}$ Very importantly, the Korean state was not captured by particular interest groups or classes. A second reason is that Park reached a deal with some of the companies and high-ranking government officials that had collaborated with the Rhee regime

16 Food aid from the US was fundamental to keep real industrial wages low.

17 The executive branch was military. The legislative power was weak and unions were repressed. This enhanced the capacity of the state to implement its policy.

18 Edwards (1999, pp.257-58): (i) the landlord class was weakened by the land reform undertaken after WWII; (ii) the domestic, merchant capitalist class, was weakened by the campaign against illicit wealth and by the nationalizations of much of the financial capital in the early 1960s; and (iii) organized labor was highly repressed and there was significant labor surplus during the 1960s and 1970s. 
(1948-1960) and that had been accused of corruption. Officials from these companies were exempted from criminal prosecution and confiscation of assets in return for collaborating with the Park regime by building factories contributing to the national reconstruction (Tan 1999, pp.86-87). As a result, the bureaucracy, especially after the second half of the 1960s, operated with great autonomy to undertake industrial policy. Moreover, Park believed that the chaebol (large companies with sufficient capital and organizational skills) were in a position to contribute to reviving the Korean economy. Also, the nationalization of the banking system played an important role since the government controlled the access to the allocation of credit. This partnership between the chaebols and the state was the foundation of the Republic of Korea's growth experience. ${ }^{19}$

The Republic of Korea approved its first 5-Year Economic Development Plan (1962-1966) as well as its 1963 stabilization program (with US assistance). From here on, the foreign exchange (tightly controlled) implications of projects and of technology transfers became crucial. The government likewise imposed import controls for domestic use, while inputs for exports were permitted. ${ }^{20}$ It switched to an export-oriented development strategy in 1962. This was prompted by the realization that the Republic of Korea had a small domestic market and that it still had a large pool of low-wage labor. Likewise, macro problems persisted (inflation, BOP deficits) and the US started phasing out aid. The rather precarious economic situation led Korean policy makers to shift gear. The export-oriented program was developed during the mid-1960s and was conceived by a group of American advisors who worked with Economic Planning Bureau and Ministry of Commerce and Industry technocrats, put together under the Joint US Korean Economic Cooperation Committee. During the 1960s firms concentrated mainly on basic assembly, beginning with the manufacture of standard, simple goods often supplying foreign multinational corporations (MNCs) from Japan and the US through Original Equipment Manufacturing (OEM). whereby a latecomer firm produces a finished product to the precise specification of a foreign MNC.

Starting in 1973, the Republic of Korea moved into the second phase of the export-orientation program. It made conscious and concerted efforts to move into higher value-added areas through complementary investments in human capital and infrastructure. This move followed in spirit that of Japan after WWII. Korean policy makers felt that the country should develop the $\mathrm{HCl}$, i.e., more skill and capital-intensive manufactures (e.g., ships, machinery, steel, automobiles, computer electronics), like Japan. Unlike the latter, however, the key reason behind this drive was to be able to manufacture weapons and defend itself. Moreover, instead of building military factories, Korean policy makers decided to build dual-use industrial complexes with a target production ratio of $70 \%$ civilian and $30 \%$ military. The machinery sector was regarded as a critical industry not only for its high value added and extensive linkages with other industries, but also for its contribution to defense.

The extent of the Republic of Korea's government involvement in the move toward an exportoriented economy was very important. The government strongly supported exporting firms through various incentives, but also acted to compel firms to export and to limit support to the most successful exporting firms. A great deal of pressure was put on firms to shift into exporting activities, with government essentially

19 Rodrik (1992) argues that what matters in the debate about the desirable quantity of government intervention is the latter's quality, and not the quantity; as well as whether or not state institutions are insulated. In his terminology, one could say that the Rhee regime was a Stackelberg leader and the government the follower, while the Park regime, it was the other way around.

20 Import controls were a key aspect of the Republic of Korea's industrial policy. Through a combination of selective controls on trade, the volume and composition of imports were the government's control. Import controls reduced the risk of new investors in new capital-intensive industries. These controls encouraged domestic manufacturers to invest on a scale sufficient to generate the increasing returns that manufacturing is subject to. 
forcing the initial export expansion of the economy. Export targets were agreed upon between the government and individual firms, with monthly export expansion meetings chaired by President Park. These targets were considered as demands, with support for firms contingent upon having met their export targets. The approach thus provided a strong incentive for firms to increase production and export capacity as strongly as possible and ensured that only the most successful and efficient firms were supported. One important role of exports was to force firms to be competitive in international markets and to encourage the inflow of technology. Technology transfer was further encouraged through external borrowing, the importation of capital goods and technology licensing through OEM. Different from other industrializing economies, FDI played only a minor role in technology transfer in the Republic of Korea. Kim (1997) shows that even in 1983 the stock of FDI in the Republic of Korea was less than a quarter of that in Singapore and less than half of that in Taipei,China and Hong Kong, China.

Like Japan's, Korean planners took an engineering approach and paid close attention to scale economies, complementary investments, and technical skills. The program aimed at achieving international competitiveness of the sectors selected, under the slogan "the exportization of all industries." This emphasis on export-led industrialization and export-led growth was reflected in the successive 5-year economic development plans of 1962-1966, 1967-1971, 1972-1976 and 1977-1981. The programs were conceived at the aggregate national level and the government played a fundamental role in addressing coordination and innovation externalities. Reforms probably mattered but the Korean government actively promoted manufactured exports through trade policy (there was little emphasis on export processing zones). In particular, the government set yearly targets, formulated financial, technical, manpower and infrastructure plans, and devised incentives for firms. Park's government made strenuous efforts to encourage private entrepreneurs, and to encourage- even harass-these entrepreneurs to engage in export activities. A number of incentives were offered to businesses that engaged in exporting, including direct subsidies and subsidized credit to exporting firms, privileges with regard to importing raw materials, as well as additional tax benefits and permission to seek financing from abroad. The currency was twice devalued-in 1961 and 1964-to stimulate exports, and restrictions on imported raw materials were gradually eased, particularly those necessary to produce goods for export. There was also an institutional context that supported the export effort. Indeed, the government created a whole set of institutions that dealt with coordination issues (the Export Promotion Subcommittee), or location of markets (the Korea Trade Promotion Corporation). The emphasis on exports was so important that President Park himself chaired the National Export Promotion Meeting of Ministers.

In 1973, Park launched the $\mathrm{HCl}$ program, partly to meet the problem generated by the increase in oil prices, and partly to make sure that the Republic of Korea became a self-reliant economy and to achieve by $1981 \$ 10$ billion exports (which Japan had reached in 1967). This would help the country pay for its imported oil. The program also aimed at achieving $\$ 1,000$ per capita income, from about $\$ 300$ at the start of the program, and the $\mathrm{HCl}$ sector accounting for at least $50 \%$ of manufacturing value added and contribute $60.5 \%$ to manufacturing exports, in 1981. At the time, international organizations thought that the program was beyond the Republic of Korea's reach and not in accordance with its comparative advantage. Hence, they discouraged the government from pursuing it.

Korean planners thought that given the country's comparative advantage in light manufacturing (e.g., apparel, footwear, electronic appliances) at the time, plus a benchmark against Japan, the Republic of Korea could make it into the $\mathrm{HCl}$. Moreover, some companies in the light manufacturing sectors had already started demanding products that the $\mathrm{HCl}$ would produce. Policy makers looked into industries deemed critical for their high value added, extensive linkages with other industries and for their contribution to defense. The specific industries "picked" were (with specific subsectors within each): (i) iron and steel, (ii) nonferrous metals, (iii) shipbuilding, (iv) machinery, 
(v) electronics, and (vi) chemicals. Sectors that had already developed considerably were excluded; and activities that were within the realm of the private sector, as well as sectors deemed impossible to develop at the time, were also excluded. ${ }^{21}$

Planners consciously chose to develop these sectors not just for the domestic market, but also aimed at achieving global market size and hence be able to export. This was to be done by relying on a group of state-owned enterprises together with private companies such as Hyundai, Samsung, and LG (there was relatively little foreign investment in the Republic of Korea because the large chaebols provided the necessary entrepreneurship). The program relied on four key pillars:

(i) Finance. The 9-year program amounted to $\$ 9.6$ billion (equivalent to the Republic of Korea's GDP at the time) and foreign funds would represent $60 \%$ of the total requirements. The government established the National Investment Fund (NIF) to finance long-term investment. The NIF interest rate was $9 \%$, while the prevailing 3-year interest rate on bank loans was $15.5 \%$. Likewise, government-controlled banks supported the program by providing policy-oriented loans on favorable terms. Other instruments used were tax credits on income earned from exports, tariff reductions on necessary imported inputs, selective protection, entry restrictions, land, and in some cases direct government involvement in industrial decision making. In terms of this latter aspect, the government tended to select the large family-owned firms - the chaebols - to enter specific industries. Over the period 1973-1979 almost 60\% of total bank loans and more than $75 \%$ of total manufacturing investment went into the selected sectors, and therefore largely into the chaebols, reducing the available funds for light manufacturing industries and small and medium enterprises (SMEs).

(ii) Land and infrastructure. The program followed a "cluster approach" where related industries were located in a single location, e.g., the machinery complex in Changwon, the petrochemical complex in Yeocheon, the electronics complex in Gumi. This required the development of not only infrastructure such as roads, port, water, and electricity, but also schools, research institutes, public administration offices, banks, hospitals, and housing facilities.

(iii) Human resources. The $\mathrm{HCl}$ drive needed the development of a technological base. Under the Presidential declaration "the scientification of all people," the Republic of Korea changed its educational curriculum and made it very applied. To achieve this, it reinforced its vocational schools, technical education, and engineering, based on the German model. Ninety-five technical high schools were divided into four types: mechanical (19), model (11), specialized (10), and general (55), to train a wide variety of technicians and skilled workers. The result is that between 1977 and 1991, Korean students placed first in the International Vocational Olympics. As a part of this process, private companies also contributed significantly as suppliers of education services for their own interests in securing needed workers. ${ }^{22}$

(iv) R\&D. The government set up several research institutes to develop science and technology, as well as industry-specific institutes and science parks. To develop its defense industry and

21 The Republic of Korea started developing its steel industry during the late 1950s and 1960s. It was mostly a failure. In 1968s, The Republic of Korea created the Pohang Iron and Steel Company, later renamed POSCO. Lee (2015, pp.84-88) provides an account of how POSCO was created and how it evolved.

22 Edwards (1999, pp.254-55) indicates that there are questions about the quality of the Republic of Korea's education, that it focused on repetition and put a heavy emphasis on moral education and discipline. He quotes Alice Amsden, who claimed that it is easy to exaggerate the role of formal education in the Republic of Korea's development. Nevertheless, this is not to dismiss the role of education and he points out that the state played a large role in, for example, depacking technology, promoting overseas training, or in coordinating the acquisition and application of existing technologies. 
given that the US was reluctant to share defense technologies, the Republic of Korea had to resort to reverse engineering.

Macroeconomic imbalances as well as political problems forced the Korean government to call off the $\mathrm{HCl}$ drive in 1979. In our view, the eventual maturing of the industries part of the $\mathrm{HCl}$ program provided the Republic of Korea with an undeniable boost to its economy. Despite all the problems, the $\mathrm{HCl}$ program helped build the foundation of many of the Republic of Korea's leading industries such as steel, shipbuilding, machinery, electronics, and petrochemicals, and later on, semiconductors and the automotive industry. The policies adopted also helped materialize a dramatic change in industrial structure throughout the 1970s. While the $\mathrm{HCl}$ contributed around 12\% to GDP in 1970, the figure had increased to more than $25 \%$ by 1980 and to more than $30 \%$ by 1988 . The success of this program can be further seen in the shift in the composition of exports, with the $\mathrm{HCl}$ increasing their share in total exports from around 13\% in 1970 to more than 50\% by 1988 (Kim, Shim, and Kim 1995, Table 7.5). By 1978, Japanese manufacturers operating in the Republic of Korea thought that Korean companies would catch up with Japan within 5 years, or were already at a comparable level, in many manufacturing sectors (Hayashi 1990, Table 2, pp.30-31). Finally, using input-output data, Lane (2017) has recently concluded that the $\mathrm{HCl}$ big push program of 1973-1979 promoted industrial development in the manufacturing sectors targeted. He shows, for example, that the real output of these industries grew $80 \%$ more than nontargeted ones during the policy period, and that the effect persisted after the program was closed down. The $\mathrm{HCl}$ interventions also led to a permanent reallocation of economic activity from light to heavy industrial sectors. He also found spillovers of the targeted sectors into other industries. Specifically, downstream buyers with strong links to treated sectors grew relatively more in terms of output, firm entry, and employment, than downstream industries with weak links. The relative price of output in downstream sectors also decreased significantly for linked versus nonlinked sectors. Lane also provides evidence that forward-linked sectors invested more in capital and increased their purchases of intermediate goods. All these results indicate that the $\mathrm{HCl}$ industrial policy generated positive pecuniary externalities to forward-linked sectors.

The $\mathrm{HCl}$ also set the stage for the Republic of Korea's transition years later into an innovationdriven economy; and strengthened backward and forward linkages among these industries as well as among related industries such as automobiles. The Republic of Korea has a rather complex economy, with a significant share of complex exports. This reflects the Republic of Korea's efforts to promote science and technology, to adopt and absorb foreign technologies, and to upgrade product quality. ${ }^{23}$ The Republic of Korea continued growing very fast, by $9.11 \%$ per annum during 1971-1990. During this period, the Republic of Korea's BOP-constrained growth rate reached $10.17 \%, 1$ percentage point above the actual growth rate (Hussain 2004, Table 14.5). Like Japan during 1953-1976, this may mean that the Republic of Korea was really not BOP constrained and that it did not grow faster than it did because it hit a capacity ceiling.

The emphasis on the chaebols to drive the shift into the $\mathrm{HCls}$ had important consequences. In particular, by encouraging these firms to diversify and grow the industrial structure and market concentration in the Republic of Korea changed dramatically. By the mid-1970s more than $90 \%$ of all commodities were produced in industries where the top three producers accounted for more than $60 \%$ of the market share, while between 1972 and 1982 the share of manufacturing output of the 20 largest firms increased from less than 10\% to nearly 30\%, with the top 10 chaebols accounting for around $50 \%$ of gross national product (GNP) by the early 1980s (Harvie and Lee 2003).

23 The Korean government established the Korean Institute of Science and Technology in 1966, and the Ministry of Science and Technology in 1967. It also set up specialized research institutes in shipbuilding, marine resources, electronics, telecommunications, energy, machinery, and chemicals. 
The promotion of strategic industries that dominated policy during the 1970 s came to an end at the start of the 1980s, when a process of trade liberalization, including an opening up of domestic markets and a reduction in export subsidies, was adopted. Many of the earlier policies were thus phased out, with the number of strategic industries gradually decreasing and the extent of preferential treatment regarding taxes and credit also reduced. More generally, a conscious decision was made by the government of President Chun Doo Hwan to limit interference in markets, with a greater reliance given to private sector decision making. In addition to trade liberalization, there was a general opening of markets-including to inward FDI, as well as efforts at financial liberalization and the promotion of SMEs. One result of this change in policy was a relatively rapid increase in inward FDI flows.

During the mid-1980s the Korean economy recovered and displayed an excellent performance. What was behind this recovery, the reforms of the early 1960s under the Joint US Korean Economic Cooperation Committee, in particular the liberalization of imports (hence the effect of market forces and comparative advantage), or the protracted effects of the $\mathrm{HCl}$ program? ${ }^{24}$ Our view is that the liberalization program and reforms had a significant impact on the transformation of the Korean economy during the 1980s. However, these reforms, alone, cannot account for the phenomenal growth of the Korean economy during 1973-1990. Moreover, this was not really a period of liberalization in the sense used in the World Development Report 1983 (World Bank 1983), where the Republic of Korea appeared as one of the least distorted economies, based on very subjective price distortion indices. ${ }^{25}$ While it is true that the Republic of Korea shifted toward the promotion of exports as US aid declined, this shift was not left to the market. It was state-sponsored. Moreover, the Republic of Korea relied very little on export processing zones. The Republic of Korea's import policy was liberal for inputs to be used for exports; but illiberal for other goods where tariff rates were high. The Korean government gave tariff protection for the domestic market on the condition that export targets were fulfilled. The reality is that from the 1960s onward, the Republic of Korea's policy linked import-substituting industrialization with export-oriented industrialization. The Republic of Korea was an outward-oriented economy but the framework was not laissez-faire.

24 Tan (1999) argued that the Korean import regime was in fact tightly controlled and was much less liberal than commonly thought. There was, for example, a clear distinction between imports for export production (allowed freely) and imports for domestic use (strictly controlled); and likewise, quantitative controls were also very important. He concludes that: "...the list of importables per se is not sufficient to determine the extent of liberalization; other factors like foreign exchange allocation, trade licensing, export obligations, custom duties, advanced deposits and overall import quotas, must also be considered. The liberalization of the mid-1960s hardly conforms to the laissez-faire paradigm, but was instead a managed liberalization" (Tan 1999, p.98).

25 The World Development Report 1983 contained an analysis that led to the conclusion that there was an inverse relationship between price distortions and economic growth, with the former explaining one-third of the latter. This finding was somewhat criticized as it was based on distortion indices that were highly subjective. The report noted, paradoxically, that the Republic of Korea, was the fourth least distorted of a group of countries analyzed. This view changed in the World Development Report 1987 (World Bank 1987), which acknowledged that the Republic of Korea had pursued an export promotion policy that combined trade liberalization with extensive intervention. The World Development Report 1989 (World Bank 1989) finally acknowledged that the Republic of Korea had had a heavily regulated financial system and that this was a key piece of its industrial policy in the 1960s and 1970s. In particular, it acknowledged that interest rates were controlled and were kept low for most of this period. 
During the 1980s, there was also increased pressure to upgrade and restructure industry, in particular to see a movement from labor and from capital-intensive production toward more technology-intensive production. Different from earlier periods, much of the impetus to shift toward higher value-added activities came from the private sector, with the government playing a more minor role in facilitating private investment in research and development (R\&D). In response to government policy and a desire to remain competitive internationally, private firms began to invest more heavily in R\&D. The share of R\&D in GNP increased from $0.74 \%$ in 1980 to 1.87\% in 1990, with the share of the private sector in R\&D increasing from below 25\% in the mid-1970s to around $75 \%$ by the mid-1980s. Despite the promotion of SMEs, the chaebols were a significant source of these investments in R\&D, taking advantage of their size and greater resources to move into higher value added and more technology-intensive stages of production.

\section{The Recent Deindustrialization Debate}

The recent literature on the relevance of industrialization for development has noted and documented that many developing countries have begun deindustrializing (i.e., a decline in the share of manufacturing in GDP and/or in the share of manufacturing employment in total employment) at relatively low levels of income per capita. Felipe, Mehta, and Rhee (2018) asked whether increased global competition and labor-displacing technological change have made it more difficult for countries to industrialize in employment. Comparing manufacturing employment and output shares. These authors show that what matters to eventually become a high-income economy is to attain a high manufacturing employment share in total employment, more than a high manufacturing output share in GDP. Output shares are weak predictors of prosperity, and are under less pressure than employment. They also show that all of today's rich non-oil economies enjoyed at least 18\% manufacturing employment shares in the past. They often did so before becoming rich. Discussing premature deindustrialization, a phenomenon documented in recent years. They also confirm the inverted- $U$ relationship between manufacturing output and employment share and income per capita: countries industrialize as income per capita increases but up to a point, after which the manufacturing share starts declining. Specifically, they show that manufacturing peaks at lower employment shares today (typically below 18\%) than in past decades (often over 30\%). Figure 6 shows that industrialization in employment is a better predictor of future prosperity than industrialization in output. ${ }^{26}$ Figure 7 shows that recent industrializers have peaked at lower employment shares; but not at lower output shares. Finally, Figure 8 shows that deindustrialization in employment begins at lower incomes than it once did. Not as obvious for output. The figures corroborate that becoming rich through industrialization has therefore become much more difficult. They argue that this is in large part the result of rapid growth in the manufacturing capabilities of some very populous countries, especially the PRC.

26 The list of economies included in the study are the following: $A R G=$ Argentina; $A U S=A u s t r a l i a ; A U T=A u s t r i a ; B A N=$ Bangladesh; $\mathrm{BEL}=$ Belgium; $\mathrm{BOL}=$ Bolivia; $\mathrm{BRA}=$ Brazil; BWA = Botswana; $\mathrm{CAN}=$ Canada; $\mathrm{CHL}=\mathrm{Chile}$; $\mathrm{COL}=\mathrm{Columbia}$; $\mathrm{CRI}=$ Costa Rica; DEN = Denmark; EGY = Egypt Arab Republic; FRA = France; FIN = Finland; GHA = Ghana; GRC = Greece; GTM = Guatamela; HND = Honduras; HKG = Hong Kong, China; IND = India; INO = Indonesia; IRE = Ireland; ITA = Italy; $\mathrm{JAP}=$ Japan; KEN = Kenya; $\mathrm{KOR}=$ Republic of Korea; $\mathrm{LUX}=$ Luxembourg; $M A L=$ Malaysia; $M A R=$ Morocco; $M E X=$ Mexico; MWI = Malawi; MUS = Mauritius; NET = the Netherlands; NGA = Nigeria; NOR = Norway; PAK = Pakistan; PAN $=$ Panama; $\mathrm{PER}=$ Peru; $\mathrm{PHI}=$ Philippines $\mathrm{POL}=$ Poland: $\mathrm{POR}=$ Portugal; $\mathrm{PRC}=$ People's Republic of China; $\mathrm{PRI}=\mathrm{Puerto}$ Rico; ROU = Romania; SEN = Senegal; SIN = Singapore; SLU = El Salvador; SMR = San Marino; SPA = Spain; SUR = Suriname; SWE = Sweden; SWI = Switzerland; SYR = Syrian Arab Republic; THA = Thailand; TTO = Trinidad and Tobago; TZA = Tanzania; UKG = United Kingdom; USA = United States; VEN = Venezuela; ZAF = South Africa; ZMB = Zambia. 


\section{Figure 6: Industrialization in Employment and Output}
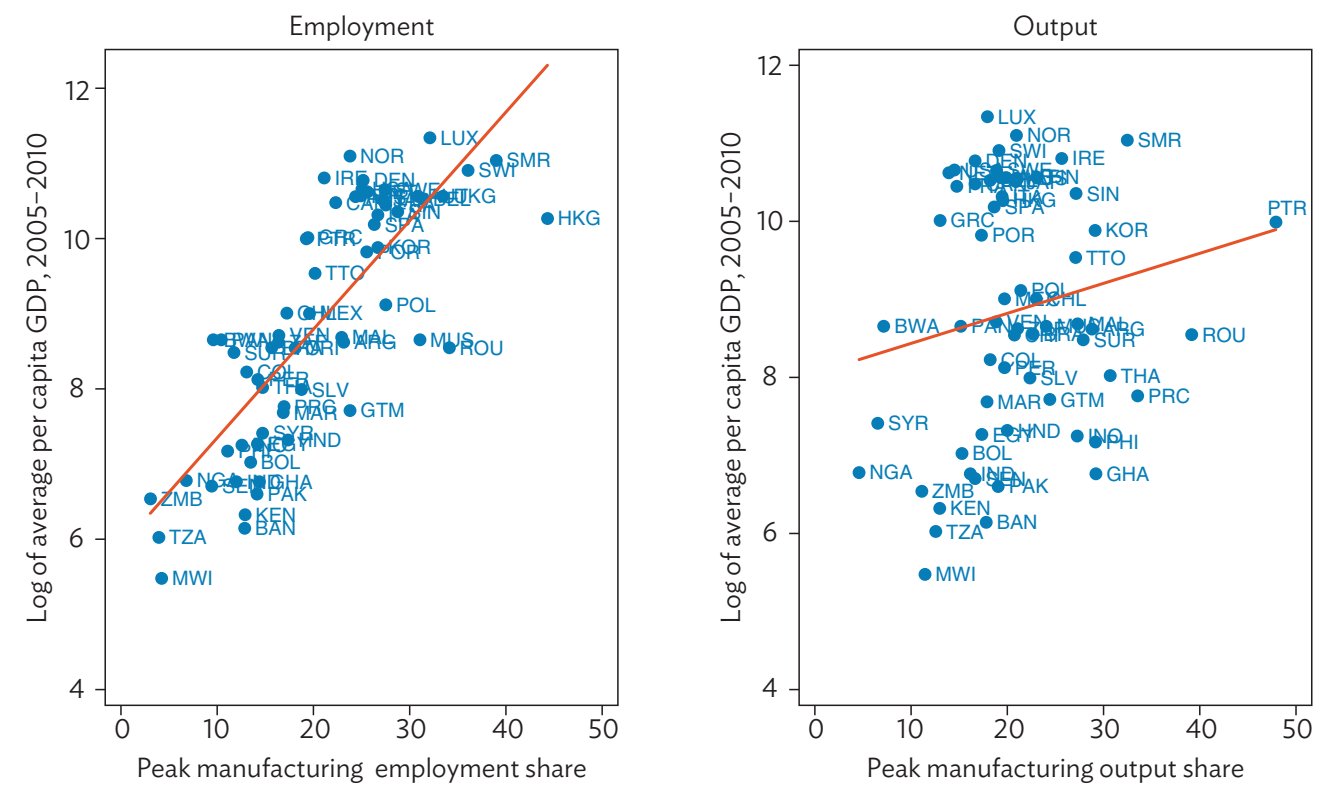

Note: $\mathrm{X}$-axis shows the level at which the 7-year moving average of the manufacturing employment and output shares peaked between 1970 and 2010. The dates of these peaks vary across countries. Only the 63 economies with adequate employment data are included. See footnote 21 for the complete list.

Source: Felipe, Jesus, Aashish Mehta, and Changyong Rhee. 2018. "Manufacturing Matters...but It's the Jobs that Count." Cambridge Journal of Economics. https://doi.org/10.1093/cje/bex086.

Figure 7: Manufacturing Shares and Year Peak was Attained
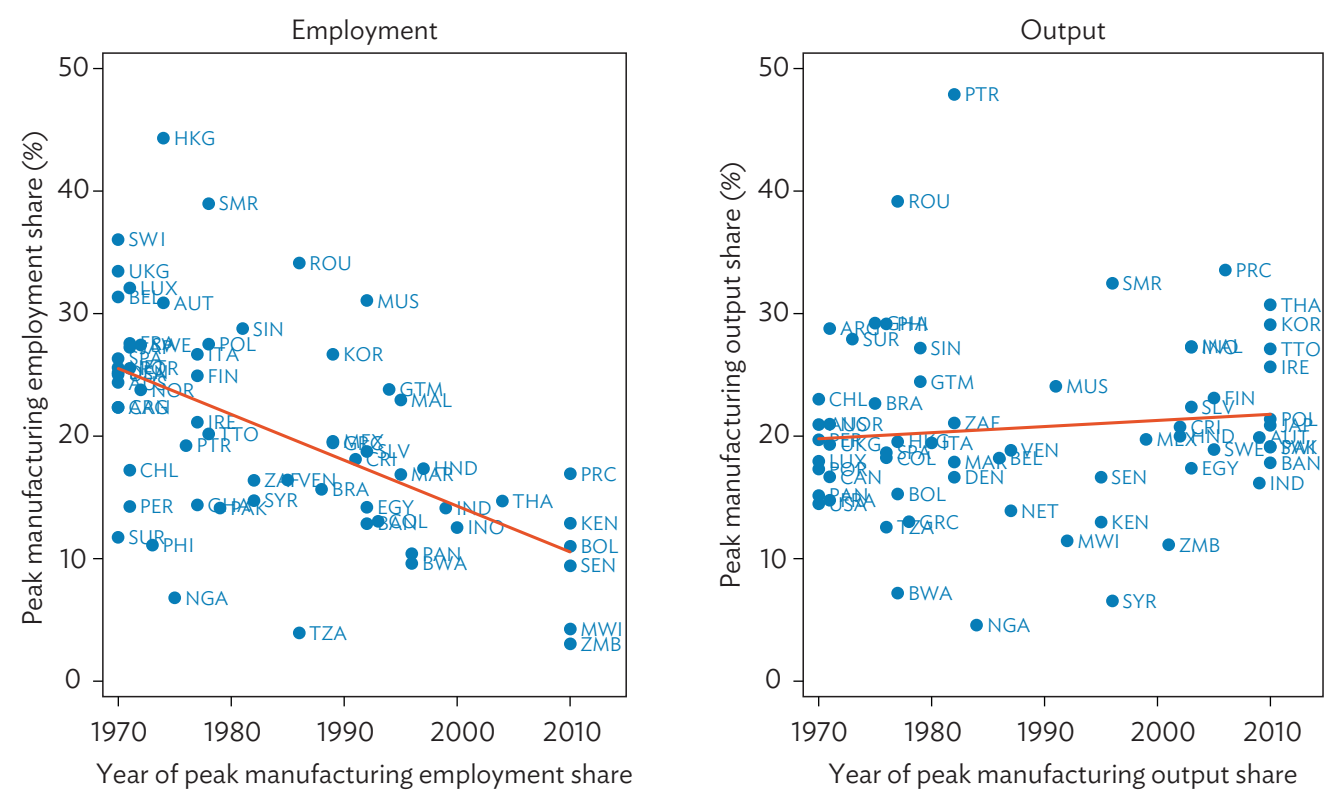

Note: $X$-axis shows the year that the 7-year moving average of the manufacturing sector's employment and output shares peaked between 1970 and 2010. Y-axis shows the manufacturing share that year. Only the 63 economies with adequate employment data are included. See footnote 21 for the complete list.

Source: Felipe, Jesus, Aashish Mehta, and Changyong Rhee. 2018. "Manufacturing Matters...but It's the Jobs that Count." Cambridge Journal of Economics. https://doi.org/10.1093/cje/bex086. 


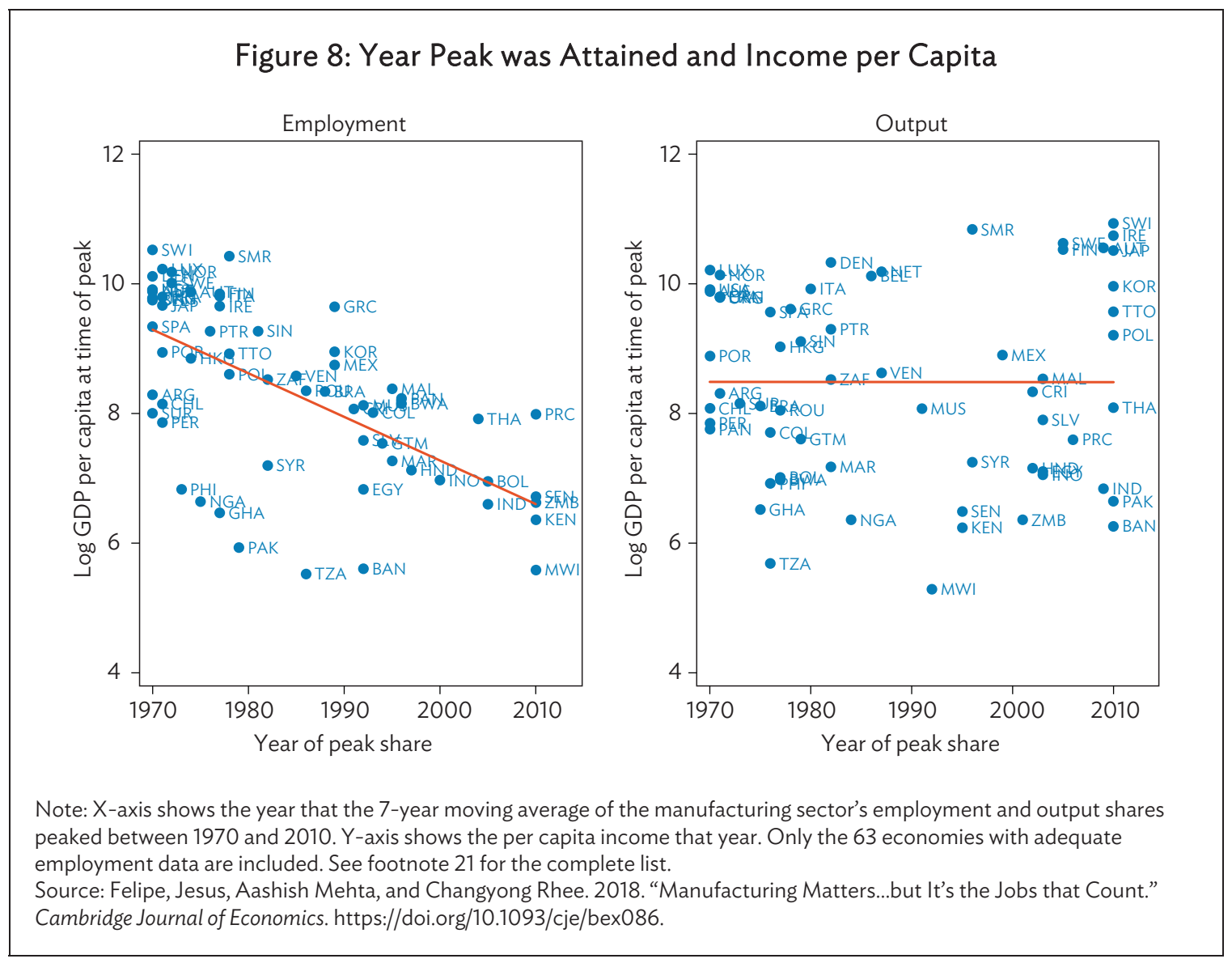

In this context, Felipe and Mehta (2016) analyze the frequently asked question of whether premature deindustrialization in employment is a result of technological change or of globalization. They argue that this presents something of a false dichotomy. The unconditional convergence explanation involves both technological changes at the national level, and globalization. This explanation holds that the internationalization of supply chains has induced more rapid increases in national manufacturing labor productivity in developing economies than in advanced economies, and that the resulting increase in competition promotes further technological change, especially in advanced economies.

Of course, one might argue that technological change occurs at the national level for exogenous reasons-other than globalization. Such an explanation is insufficiently rich to explain all the results in their paper. It does not explain why manufacturing labor productivity grew faster (relative to aggregate productivity) in lower-income economies. Felipe and Mehta (2016) provide three pieces of evidence that show that the spread of manufacturing capabilities to populous, lower-income countries, seems to be an integral part of the story. First, manufacturing labor productivity has grown more rapidly in poorer countries (not just relative to aggregate labor productivity-as we show in this paper). Second, even if these productivity trends might be considered suspect due to the usual problems of tracking output across time and countries, the employment data seem to tell the same story: manufacturing jobs have shifted from countries with initially more productive manufacturing sectors to countries with initially less productive manufacturing sectors (Figures 9 and 10). This is hard to reconcile with similar rates of productivity growth worldwide, especially as wages have at the same time risen faster in the destination countries. Third, if the only trend of relevance was rapid labor productivity growth in manufacturing 
everywhere, manufacturing's share of global employment should have fallen relative to its share of global output. It did not. Rather, while productivity in manufacturing grew faster than aggregate labor productivity within nations, the ongoing relocation of manufacturing jobs from more to less productive but more populous countries-especially the PRC-canceled this out. This permitted the global economy to retain constant shares of both employment and output in manufacturing. Thus, laborsaving technological change on its own is insufficient as an explanation for national deindustrialization trends.

What are the implications of deindustrialization, in particular for the developing economies? In the advanced countries, the effects of deindustrialization are clear as they have been felt for decades: the very high labor productivity growth rates of manufacturing vis-à-vis the rest of the economy meant that the share of manufacturing employment started declining steadily as workers moved to service industries such as education, health, entertainment, and public administration. The main consequence was a significant increase in inequality. Those workers with the skills that the new service economy rewards handsomely (e.g., bankers, consultants, engineers, lawyers, logistics experts) could earn very high wages. Millions of less skilled workers, on the other hand, ended in jobs that did not pay well to start with, and without opportunities for higher wages as productivity in these activities is minimal.

Figure 9: Share of Manufacturing in Global Employment with Regional Contributions (63 countries that have all necessary employment data)

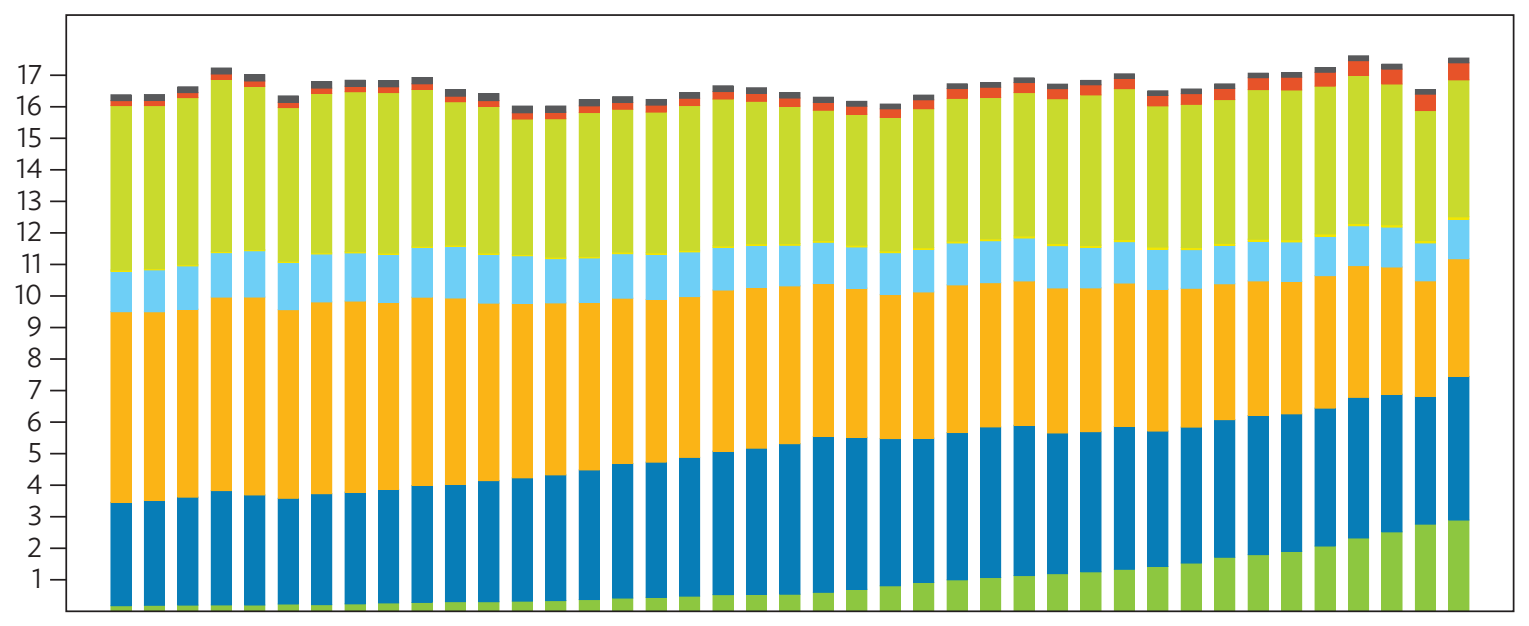

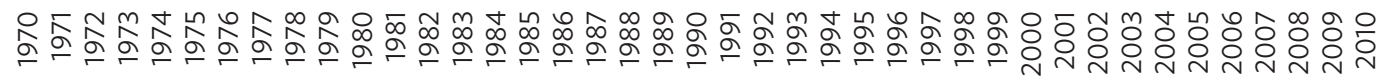
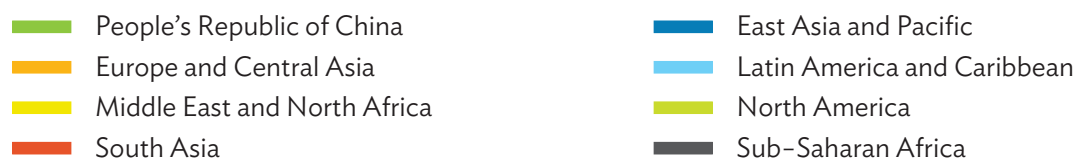

Source: Felipe, Jesus, and Aashish Mehta. 2016. “Deindustrialization? A Global Perspective.” Economics Letters 149: 148-51. 
Figure 10: Share of Manufacturing in Global Output with Regional Contributions

(64 countries that have all necessary employment data)

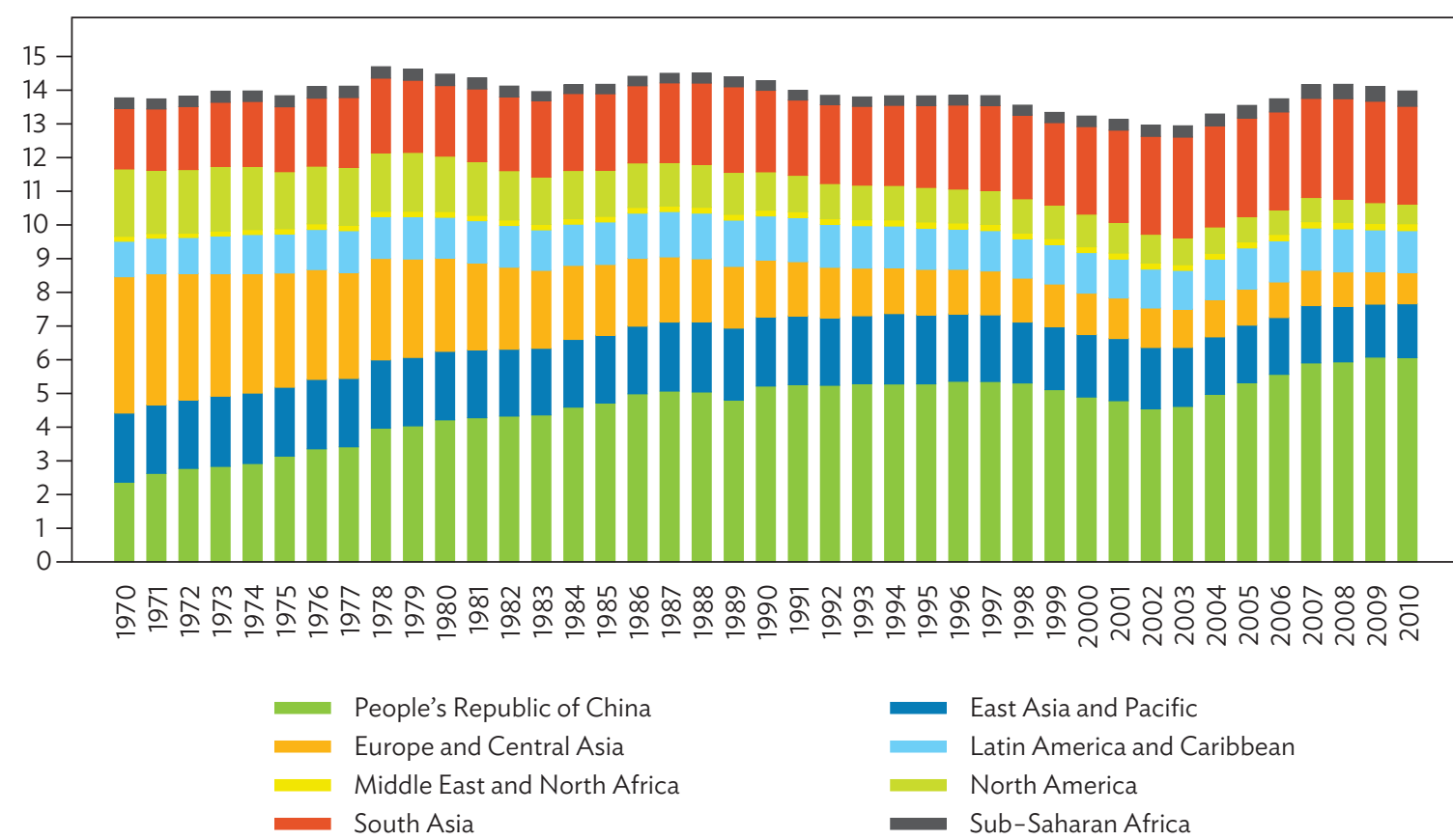

GGDC = Groningen Growth and Development Centre.

Note: GGDC employment data, excluding West Germany and Taipei,China, augmented with 23 non-GGDC countries from our main data set. San Marino is excluded.

Source: Felipe, Jesus, and Aashish Mehta. 2016. “Deindustrialization? A Global Perspective." Economics Letters 149: 148-51.

What is happening in the developing world? What is clear is that, as far as we know given the historical experience of the advanced economies, manufacturing is the escalator to eventually reach high income. Activities in this sector are subject to increasing returns to scale, manufacturing can potentially absorb millions of workers, and, through exports, the sector offers the possibility to satisfy a very large demand. This is how the successful Asian economies progressed during the 1960s-1980s. However, the evidence discussed above indicates that it will be very difficult for today's developing countries (with a few exceptions) to enjoy the benefits of industrialization: globalization and technological progress have combined to make industrialization a very difficult endeavor. Peak levels of manufacturing employment shares are much lower today than in previous decades, deindustrialization starts at lower income levels, and the labor-absorbing potential of manufacturing of workers from agriculture is much lower due to the fact that technologies in manufacturing have become highly labor saving. This means that today's developing countries are becoming service economies without having reached the industrialization levels that the advanced Western economies achieved. With the exception of a small group of already high-income Asian economies, this seems to be the curse of most other developing nations across the globe. The PRC, the great absorber of the transfer of manufacturing employment from Europe and the US, has had much to do with closing the manufacturing opportunity to many other developing nations. 
What is the future of workers in most developing nations? Chen et al. (2018) document that, contrary to what many seem to think, employment has not globalized in recent decades. Quite the opposite, the share of employment in tradable activities has fallen significantly, in both advanced and developing countries. What sectors are generating employment? Nontradable services, e.g., hotels and restaurants, personal services, retail trade. The 'problem' with these sectors is that, in general, their productivity is low. Hence, it is very difficult for workers in these sectors to experience significant pay increases. It is not clear how the productivity of waiters or of sales clerks will increase in the future to justify higher salaries, if the share of those employed in tradable activities that pay high salaries (engineers either in manufacturing or in services) shrinks. 


\section{REFERENCES}

Amable, Bruno. 2000. "International Specialisation and Growth." Structural Change and Economic Dynamics 11 (4): 413-31.

Ang, James B., Kakob B. Madsen, and Peter E. Robertson. 2015. "Export Performance of the Asian Miracle Economies: The Role of Innovation and Product Variety." Canadian Journal of Economics 48 (1): 273-309.

Aoki, Shuhei, Julen Esteban-Pretel, Tetsuji Okazaki, and Yasuyuki Sawada. 2011. "The Role of the Government in Facilitating TFP Growth during Japan's Rapid Growth Era." In Community, Market and State Development, edited by Kaliappa Kalirajan and Keijiro Otsuka. New York: Palgrave MacMillan.

Asian Development Bank (ADB). 2007. Growth Amid Change in Developing Asia. Manila.

Banister, Judith. 2005. "Manufacturing Employment in China." Monthly Labor Review 128 (7): 11-29.

Baumol, William J. 1967. "Macroeconomics of Unbalanced Growth: The Anatomy of Urban Crisis." American Economic Review 57 (3): 415-26.

Chakravarty, Sangeeta, and Arup Mitra. 2009. "Is Industry Still the Engine of Growth? An Econometric Study of the Organized Sector Employment in India." Journal of Policy Modeling 31 (1): 22-35.

Chen, Liming, Jesus Felipe, Andrew Kam, and Aashish Mehta. 2018. “Is Employment Globalizing?” Manuscript.

Chenery, Hollis, Sherman Robinson, and Moshi Syrquin. 1986. Industrialization and Economic Growth. Oxford: Oxford University Press.

Edwards, Chris. 1999. “Korean Contrast.” In Industrial Policy in East Asia: Lessons for Malaysia, edited by Jomo Kwame Sundaram and Tan Kock Wah, 75-138. Kuala Lumpur: University of Malaya Press.

Fagerberg, Jan. 2000. "Technological Progress, Structural Change and Productivity Growth: A Comparative Study." Structural Change and Economic Dynamics 11 (4): 393-411.

Fagerberg, Jan, and Bart Verspagen. 1999. "Modern Capitalism in the 1970s and 1980s." In Growth, Employment and Inflation, edited by Mark Setterfield. Houndmills, Basingstoke: MacMillan.

- 2002. "Technology-Gaps, Innovation-Diffusion and Transformation: An Evolutionary Interpretation." Research Policy 31 (8-9): 1291-304.

Felipe, Jesus, ed. 2015. Development and Modern Industrial Policy in Practice: Issues and Country. Cheltenham, UK and Northampton, MA: Edward Elgar and Asian Development Bank.

Felipe, Jesus, Connie Bayudan-Dacuycuy, and Matteo Lanzafame. 2016. "The Declining Share of Agricultural Employment in China: How Fast?" Structural Change and Economic Dynamics 37: 127-37. 
Felipe, Jesus, Utsav Kumar, Arnelyn Abdon, and Marife Bacate. 2012. "Product Complexity and Economic Development." Structural Change and Economic Dynamics 23 (1): 36-68.

Felipe, Jesus, Miguel León-Ledesma, Matteo Lanzafame, and Gemma Estrada. 2009. "Sectoral Engines of Growth in Developing Asia: Stylized Facts and Implications." Malaysian Journal of Economic Studies 46 (2): 107-33.

Felipe, Jesus, and Aashish Mehta. 2016. “Deindustrialization? A Global Perspective.” Economics Letters 149: 148-51.

Felipe, Jesus, Aashish Mehta, and Changyong Rhee. 2018. "Manufacturing Matters...but It's the Jobs that Count." Cambridge Journal of Economics. https://doi.org/10.1093/cje/bex086.

Guerrieri, Paulo, and Valentina Meliciani. 2005. "Technology and International Competitiveness: The Interdependence between Manufacturing and Producer Services." Structural Change and Economic Dynamics 16 (4): 489-502.

Hansen, Jorgen Drud, and Jie Zhang. 1996. "A Kaldorian Approach to Regional Economic Growth in China." Applied Economics 28 (6): 679-85.

Harvie, Charles, and Hyun-Hoon Lee. 2003. Korea's Economic Miracle: Fading or Reviving? United Kingdom: Palgrave Macmillan.

Hayashi, Fumio, and Edward C. Prescott. 2008. "The Depressing Effect of Agricultural Institutions on the Prewar Japanese Economy." Journal of Political Economy 116 (4): 573-632.

Hayashi, Takeshi. 1990. The Japanese Experience in Technology: From Transfer to Self-Reliance. Tokyo: United Nations University Press.

Helper, Susan, Timothy Krueger, and Howard Wial. 2012. Why Does Manufacturing Matter? Which Manufacturing Matters? A Policy Framework. Washington, DC: Brookings Policy Framework Manufacturing Report.

Hidalgo, César A., and Ricardo Hausmann. 2009. "The Building Blocks of Economic Complexity." PNAS 106 (26): 10570-75.

Hussain, M. Nureldin. 2004. "The Balance of Payments Constraint and Growth Rate Differences among African and East Asian Economies." In Essays on Balance of Payments Constrained Growth: Theory and Evidence, edited by John McCombie and Anthony Thirlwall. London and New York: Routledge.

Johnson, Chalmers. 1982. MITI and the Japanese Miracle: The Growth of Industrial Policy, 1925-1975. Stanford: Stanford University Press.

Jung, Ku-Hyun. 1994. “Changing Business-Government Relations in Korea.” In The State and Economic Development: Lessons from the Far East, edited by Robert Fitzgerald, 76-97. Singapore: Toppan Company. 
Kaldor, Nicholas. 1966. Causes of the Slow Rate of Growth of the United Kingdom. Cambridge: Cambridge University Press.

1967. Strategic Factors in Economic Development. Ithaca, New York: Cornell University Press.

.1970. "The Case for Regional Policies.” Scottish Journal of Political Economy 17 (3): 337-48.

Kathuria, Vinish, and Rajesh Raj Natarajan. 2009. Is Manufacturing an Engine of Growth in India? Analysis in the Post-Nineties. In Pathways to Industrialisation in the 21st Century. New Challenges and Emerging Paradigms. A paper for the UNI-WIDER/UNU-MERIT/UNIDO Workshop, Maastricht, 22-23 October.

Kim, Joon-Kyung, Sang Dal Shim, Jun-II Kim. 1995. "The Role of the Government in Promoting Industrialization and Human Capital Accumulation in Korea." In Growth Theories in Light of the East Asian Experience, NBER-East Asia Seminar on Economics, Volume 4, edited by Takatoshi Ito and Anne O. Krueger, 181-200. Chicago and London: University of Chicago Press.

Kim, Linsu. 1997. From Imitation to Innovation: Dynamics of Korea's Technological Learning. Boston: Harvard Business School Press.

Lane, Nathaniel. 2017. "Manufacturing Revolutions-Industrial Policy and Networks in South Korea." Job market paper at the Institute for International Economic Studies, Stockholm.

Lee, Keun. 2015. "Capability Building and Industrial Diversification." In Development and Modern Industrial Policy in Practice: Issues and Country Experiences, edited by Jesus Felipe, 70-93. Cheltenham, UK and Northampton, MA: Edward Elgar.

Lewis, W. Arthur. 1955. The Theory of Economic Growth. London: Goerge Allen \& Unwin.

Maddison, Angus. 1995. Monitoring the World Economy. Paris: OECD Development Centre.

Maroto-Sánchez, Andrés, and Juan R. Cuadrado-Roura. 2009. "Is Growth of Services an Obstacle to Productivity Growth? A Comparative Analysis." Structural Change and Economic Dynamics 20 (4): 254-65.

McCombie, John, and Anthony Thirlwall. 1994. Economic Growth and the Balance-of-Payments Constraint. New York: St. Martin's Press.

Minami, Ryōshin. 1994. The Economic Development of Japan. New York: St. Martin's Press.

Murphy, Kevin M., Andrei Shleifer, and Robert W. Vishny. 1989. "Industrialization and the Big Push." Journal of Political Economy 97 (5): 1003-26.

Myrdal, Gunnar. 1957. Economic Theory and Underdeveloped Regions. London: Duckworth.

Park, Se-Hark. 2009. "Linkages between Industry and Services and Their Implications for Urban Employment Generation in Developing Countries." Journal of Development Economics 30 (2): 359-79. 
Peneder, Michael. 2003. "Industrial Structure and Aggregate Growth." Structural Change and Economic Dynamics 14 (4): 427-48.

Pieper, Ute. 2000. "Deindustrialization and the Social and Economic Sustainability Nexus in Developing Countries: Cross-Country Evidence on Productivity and Employment." Journal of Development Studies 36 (4): 66-99.

Reinert, Erik S. 2007. How Rich Countries Got Rich... and Why Poor Countries Stay Poor. London: Constable.

Rodrik, Dani. 1992. "Political Economy and Development Policy.” European Economic Review 36: 329-36.

2009. Growth after the Crisis. Cambridge, MA: Harvard Kennedy School.

_.2010. "Making Room for China in the World Economy." American Economic Review 100 (2): 8993.

_. 2013. “Unconditional Convergence in Manufacturing." Quarterly Journal of Economics 128 (1): 165-204.

Rosenstein-Rodan, Paul Narcyz. 1943. "Problems of Industrialisation of Eastern and South-Eastern Europe.” The Economic Journal 53 (210/211): 202-11.

Rowthorn, Robert, and Ramana Ramaswamy. 1997. "Deindustrialization: Causes and Implications." IMF Working Paper No. WP/97/42. Washington, DC: International Monetary Fund.

. 1999. “Growth, Trade, and Deindustrialization.” IMF Staff Papers 46 (1): 18-41.

Smith, Adam. (1776) 2003. The Wealth of Nations. London: William Strahan and Thomas Cadell. Reprint, New York: Bantam Dell. Citation refers to the Bantam Dell edition.

Szirmai, Adam. 2012. "Industrialisation as an Engine of Growth in Developing Countries 1950-2005." Structural Change and Economic Dynamics 23 (4): 406-20.

Szirmai, Adam, and Bart Verspagen. 2011. "Manufacturing and Economic Growth in Developing Countries, 1950-2005." UNU-MERIT Working Paper No. 2011-069. Maastricht, the Netherlands: United Nations University-Maastricht Economic and Social Research and Training Center on Innovation and Technology and Maastricht University.

2015. "Manufacturing and Economic Growth in Developing Countries, 1950-2005." Structural Change and Economic Dynamics 34: 46-59.

Tan, Kock Wah. 1999. "South Korea." In Industrial Policy in East Asia: Lessons for Malaysia, edited by Jomo Kwame Sundaram and Tan Kock Wah, 75-138. Kuala Lumpur: University of Malaya Press.

Thirlwall, Anthony. 1979. "The Balance of Payments Constraint as an Explanation of the International Growth Rate Differences.” BNL Quarterly Review 32 (128): 45-53.

Thomas, Jayan Jose. 2009. "Why is Manufacturing Not the Engine of India's Economic Growth, Examining Trends, 1959-60 to 2008/9." Mimeo, New Delhi. 
Timmer, Marcel, and Gaaitzen J. de Vries. 2009. "Structural Change and Growth Accelerations in Asia and Latin America: A New Sectoral Data Set.” Cliometrica 3 (2): 165-90.

Timmer, Marcel, Gaaitzen J. de Vries, and Klaas de Vries. 2015. "Patterns of Structural Change in Developing Countries." In Routledge Handbook of Industry and Development, edited by John Weiss and Michael Tribe, 65-83. London and New York: Routledge.

United Nations Industrial Development Organization (UNIDO). 2013. Industrial Development Report 2013 Sustaining Employment Growth: The Role of Manufacturing and Structural Change. Vienna.

Wan, Henry Y. 2004. Economic Development in a Globalized Environment: East Asian Evidences. Kluwer Academic Publishers.

World Bank. 1983. World Development Report 1983. New York: Oxford University Press.

1987. World Development Report 1987. New York: Oxford University Press.

1989. World Development Report 1989. New York: Oxford University Press.

Young, Allyn A. 1928. "Increasing Returns and Economic Progress." History of Economic Thought Articles 38: 527-42. 


\section{Asia's Industrial Transformation: The Role of Manufacturing and Global Value Chains (Part 1)}

The single most important factor that explains East Asia's development success was its fast structural transformation toward industrialization, manufacturing in particular. Workers moved out of agriculture into manufacturing, and the sector diversified and upgraded its structure. Manufacturing activities are subject to increasing returns to scale, and many manufacturing goods have high income elasticities of demand. As a consequence, the sector is referred to as the "engine of growth." The paper documents the extent of structural transformation in developing Asia and analyzes the relationship between the exportled growth model and industrialization. It also reviews the industrialization experiences of Japan and the Republic of Korea.

\section{About the Asian Development Bank}

ADB's vision is an Asia and Pacific region free of poverty. Its mission is to help its developing member countries reduce poverty and improve the quality of life of their people. Despite the region's many successes, it remains home to a large share of the world's poor. ADB is committed to reducing poverty through inclusive economic growth, environmentally sustainable growth, and regional integration.

Based in Manila, ADB is owned by 67 members, including 48 from the region. Its main instruments for helping its developing member countries are policy dialogue, loans, equity investments, guarantees, grants, and technical assistance. 